\title{
Hydrothermal origin of halogens at Home Plate, Gusev Crater
}

\author{
Mariek E. Schmidt, ${ }^{1}$ Steven W. Ruff, ${ }^{2}$ Timothy J. McCoy, ${ }^{1}$ William H. Farrand, ${ }^{3}$ \\ Jeffrey R. Johnson, ${ }^{4}$ Ralf Gellert, ${ }^{5}$ Douglas W. Ming, ${ }^{6}$ Richard V. Morris, ${ }^{6}$ \\ Nathalie Cabrol, ${ }^{7}$ Kevin W. Lewis, ${ }^{8}$ and Christian Schroeder $^{6}$ \\ Received 25 October 2007; revised 22 February 2008; accepted 28 April 2008; published 19 June 2008.
}

[1] In the Inner Basin of the Columbia Hills, Gusev Crater is Home Plate, an $80 \mathrm{~m}$ platform of layered clastic rocks of the Barnhill class with microscopic and macroscopic textures, including a bomb sag, suggestive of a phreatomagmatic origin. We present data acquired by the Spirit Mars Exploration Rover by Alpha Particle X-Ray Spectrometer (APXS), Mössbauer Spectrometer, Miniature Thermal Emission Spectrometer (MiniTES), and Panoramic Camera (Pancam) for the Barnhill class rocks and nearby vesicular Irvine class basalts. In major element concentrations (e.g., $\mathrm{SiO}_{2}, \mathrm{Al}_{2} \mathrm{O}_{3}, \mathrm{MgO}$, and $\mathrm{FeO} *$ ), the two rock classes are similar, suggesting that they are derived from a similar magmatic source. The Barnhill class, however, has higher abundances of $\mathrm{Cl}, \mathrm{Br}, \mathrm{Zn}$, and Ge with comparable $\mathrm{SO}_{3}$ to the Irvine basalts. Nanophase ferric oxide (np ox) and volcanic glass were detected in the Barnhill class rocks by Mössbauer and Mini-TES, respectively, and imply greater alteration and cooling rates in the Barnhill than in the Irvine class rocks. The high volatile elements in the Barnhill class agree with volcanic textures that imply interaction with a briny groundwater during eruption and (or) by later alteration. Differences in composition between the Barnhill and Irvine classes allow the fingerprinting of a Na-Mg-Zn-Ge-Cl-Br $\left( \pm \mathrm{Fe} \pm \mathrm{Ca} \pm \mathrm{CO}_{2}\right)$ brine with low $\mathrm{S}$. Nearby sulfate salt soils of fumarolic origin may reflect fractionation of an acidic S-rich vapor during boiling of a hydrothermal brine at depth. Persistent groundwater was likely present during and after the formation of Home Plate.

Citation: Schmidt, M. E., et al. (2008), Hydrothermal origin of halogens at Home Plate, Gusev Crater, J. Geophys. Res., 113, E06S12, doi:10.1029/2007JE003027.

\section{Introduction}

[2] Since 2004, the twin Mars Exploration Rovers have sent back invaluable data that point toward the presence of past surface water along geologic transects on opposite sides of the planet. Until the investigation of the Inner Basin of the Columbia Hills began in late 2005, evidence for water found by the Spirit rover in Gusev Crater had been relatively minor compared to the laminated, jarosite and hematite-bearing sedimentary rocks found by the Opportunity rover in Meridiani Planum [Squyres et al., 2004b]. Spirit was initially sent to Gusev Crater because the long canyon Ma'adim Vallis enters the crater from the south and

\footnotetext{
${ }^{1}$ Department of Mineral Sciences, National Museum of Natural History, Smithsonian Institution, Washington, D. C., USA.

${ }^{2}$ School of Earth and Space Exploration, Arizona State University, Tempe, Arizona, USA.

${ }^{3}$ Space Science Institute, Boulder, Colorado, USA.

${ }^{4}$ U.S. Geological Survey, Flagstaff, Arizona, USA.

${ }^{5}$ Guelph-Waterloo Physics Institute, University of Guelph, Guelph, Ontario, Canada.

${ }^{6}$ NASA Johnson Space Center, Houston, Texas, USA.

${ }^{7}$ NASA Ames Research Center, Moffett Field, California, USA.

${ }^{8}$ Division of Geological and Planetary Sciences, California Institute of Technology, Pasadena, California, USA.

Copyright 2008 by the American Geophysical Union. 0148-0227/08/2007JE003027\$09.00
}

suggests that it was once inundated by a flood or lake [Cabrol et al., 2003; Golombek et al., 2003]. The rocks first examined by Spirit on the Gusev Plains were basalts [Squyres et al., 2004a] with evidence for aqueous processes limited to partially filled vugs and veins and weathering rinds formed by low $\mathrm{pH}$ fluids at low water: rock ratios [Haskin et al., 2005; Hurowitz et al., 2006a].

[3] Spirit began to encounter older, pervasively to moderately altered, goethite-bearing clastic rocks that were affected by water and acid volatiles once it reached the Columbia Hills [Ming et al., 2006; Morris et al., 2006; Squyres et al., 2006]. Evidence of water became even more compelling after Spirit descended into the Inner Basin of the Columbia Hills and volcanic rocks and soils began to hint at fossil hydrothermal system. In particular, Spirit came across hydrated sulfate salt Paso Robles class soils of likely fumarolic origin [Yen et al., 2008] and recently discovered amorphous silica deposits that are either sinter or severely acid bleached hydrothermal deposits [Squyres et al., 2008; D.W. Ming et al., Geochemical properties of rocks and soils in Gusev Crater, Mars: Cumberland Ridge to Home Plate, manuscript in preparation, 2008].

[4] Home Plate, the most conspicuous geologic feature so far investigated in the Inner Basin has yielded strong evidence for past near-surface water. Home Plate is an $80 \mathrm{~m}$ diameter light-toned outcrop platform of laminated, 


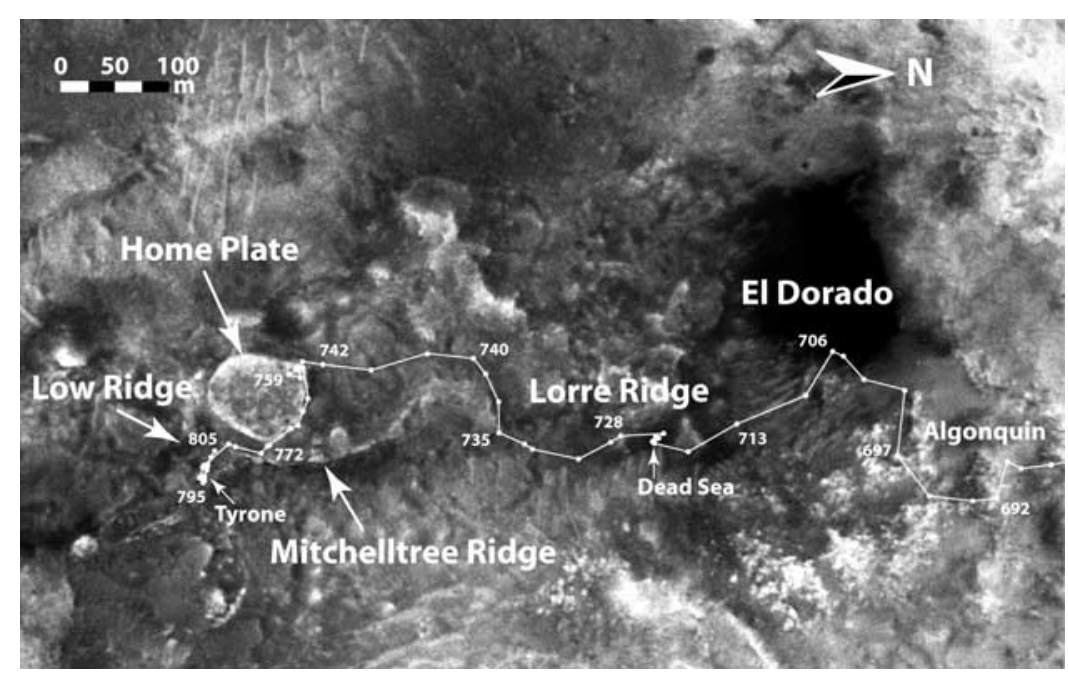

Figure 1. MOC image of the Inner Basin of the Columbia Hills with Spirit's traverse until sol (Martian day) 805 when Spirit reached its winter haven site on a north facing slope. Sol numbers are indicated.

massive, to cross-bedded strata, thought to be pyroclastic and likely hydromagmatic in origin [Squyres et al., 2007]. The Barnhill class rocks that comprise Home Plate are compositionally nearly homogenous and similar to nearby Irvine class vesicular alkali-rich basalts. Concentrations of volatile elements that have strong affinity for aqueous solutions, including the halogens $\mathrm{Cl}$ and $\mathrm{Br}$ and siderophile metals $\mathrm{Ge}$ and $\mathrm{Zn}$, are higher at Home Plate than nearby basalts.

[5] In this paper, we present the observations made by the Athena Payload [Squyres et al., 2003] at the northwest corner of Home Plate and nearby basaltic rocks. The payload includes the Panoramic camera (Pancam) [Bell et al., 2003], three engineering cameras [Squyres et al., 2003], and the Miniature Thermal Emission Spectrometer (MiniTES) [Christensen et al., 2003]. Instruments on the rover's arm, or instrument deployment device (IDD) include the Alpha Particle X-ray Spectrometer (APXS) [Rieder et al., 2003], which analyzes major and some minor element concentrations in rocks and soils; the Mössbauer Spectrometer [Klingelhöfer et al., 2003], which analyzes for Febearing mineralogy; the Microscopic Imager camera (MI) [Herkenhoff et al., 2003]; and the Rock Abrasion Tool (RAT) [Gorevan et al., 2003], which brushes dust off of rock surfaces. We then infer the composition and character of a Cl-rich hydrothermal brine and suggest that it was incorporated during fragmentation and (or) later alteration.

\section{Geologic Traverse}

[6] Spirit has analyzed dozens of diverse rocks and soils in Gusev Crater and the vicinity of Home Plate is particularly diverse and includes ultramafic and silica-rich deposits (R.E. Arvidson et al., Spirit Mars rover mission to the Columbia Hills, Gusev Crater: Mission overview and selected results from the Cumberland Ridge to Home Plate, submitted to Journal of Geophysical Research, 2008). More commonly, however, Spirit has encountered basalts along its traverse. These basalts vary in texture, degree of alteration, and in alkali element concentrations [Squyres et al., 2006; McSween et al., 2004, 2006a, 2006b]. This paper focuses on the two main basaltic units in the Inner Basin: the Home Plate layered tephra deposits and vesicular basalts that cap surrounding ridges and make up a lag deposit on top of Home Plate.

[7] Images of Home Plate from orbit by the Mars Orbital Camera (MOC) and later by High Resolution Imaging Experiment (HiRISE) (Figure 1) revealed a light-toned subcircular structure. After entering the Inner Basin, Spirit drove south along the Lorre Ridge, which consists of

Figure 2. False color Pancam (L257) images of rock targets discussed in text. (a) The Dead_Sea site, where Arad_Samra, a white powdery soil, was unearthed by the rover's wheel, and Masada, a vesicular basalt next to Arad, was examined. An arrow indicates Masada. The field of view is approximately $80 \mathrm{~cm}$. (b) Image of Barnhill, where Barnhill_Ace (massive upper section) and Barnhill_Fastball (coarse-grained layered section) were examined by IDD. Note arrow pointing to bomb sag, where layers were bent by the impact of the $3 \mathrm{~cm}$ projectile. (c) The Gibson Panorama mosaic of the $1-2 \mathrm{~m}$ tall northwest face of Home Plate that was imaged while Spirit analyzed the Barnhill targets. The rover took these images while at a $27^{\circ}$ tilt, causing the apparent "U" shape of the mosaic. This section contains two main units, the lower, coarser-grained unit, which includes Barnhill at the lower part of section and an upper, laminated, cross-bedded unit. (d) The rock target Posey_Manager that was brushed by the RAT (dark blue circle; $4.5 \mathrm{~cm}$ diameter) and analyzed by the IDD. Posey is a float rock next to Barnhill that presumably fell from the upper, cross-bedded unit of Home Plate. (e) The rock target CoolPapaBell from the top surface of Home Plate. The target was analyzed at two brushed spots $(4.5 \mathrm{~cm}$ diameter), CoolPapaBell_Crawford and CoolPapaBell_Stars. 
basaltic scoria. Spirit approached Home Plate on sol 744, climbing on top of the northwest edge (Figure 1) before descending the structure and traversing clockwise to the east and southeast. The rover reached a north facing slope on Low Ridge on sol 805 where it rode out the Martian winter in order to remain energy positive. Once the solar energy became favorable again in the spring (sol 1055), Spirit examined a nearby vesicular basalt.

\subsection{Vesicular Basalts of the Inner Basin}

[8] Wind abraded vesicular basalt rocks, ranging from $20 \mathrm{~cm}$ to $1 \mathrm{~m}$ in diameter comprise a capping unit on surrounding ridges and a lag deposit on top of Home Plate (Figure 1). These basalts belong to the Irvine class, a group that is rich in alkali elements and contains pyroxene and magnetite (see later sections). Rubble piles of Irvine class basalts in the Inner Basin are geographically and compositionally restricted.
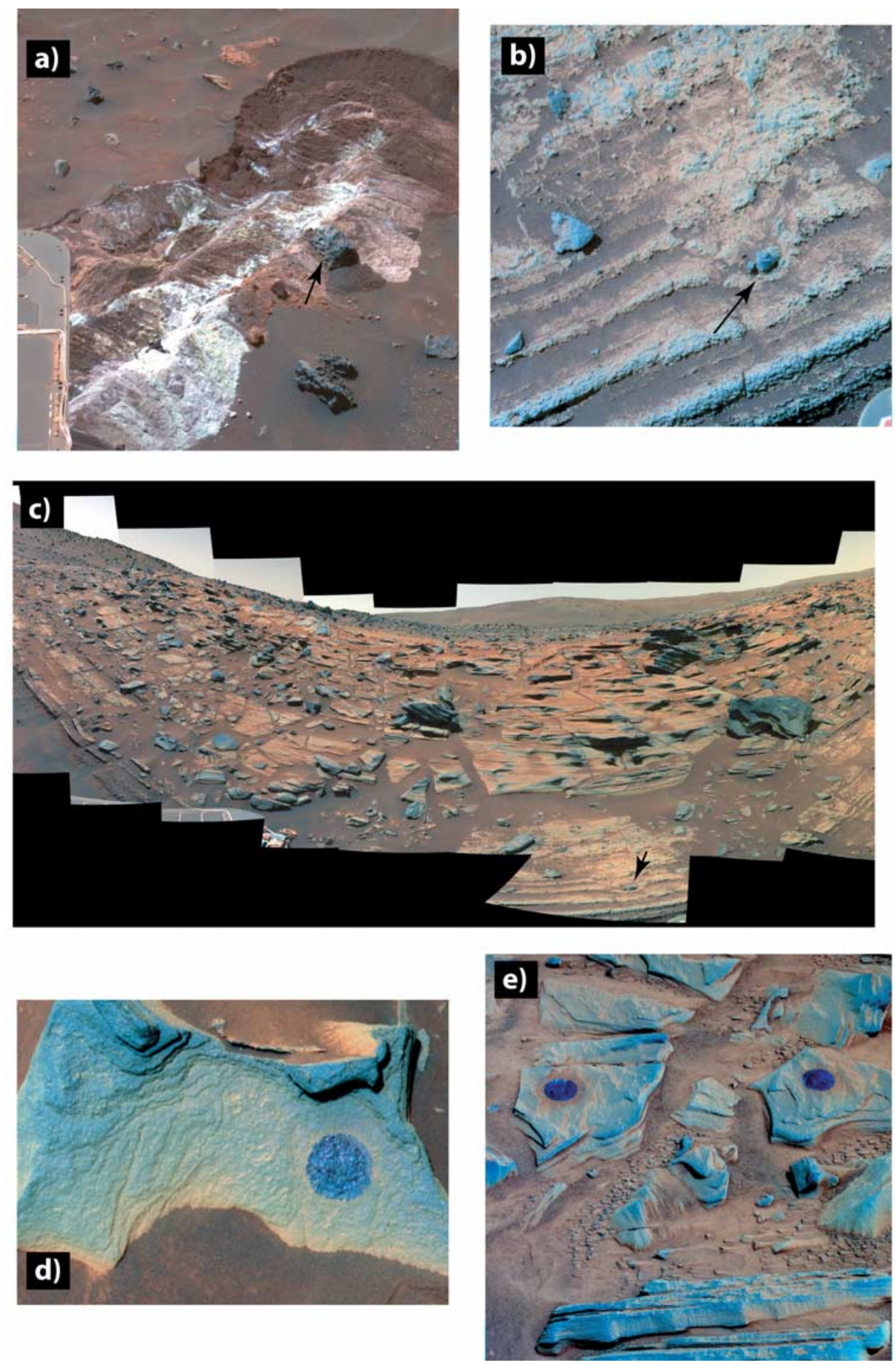

Figure 2 

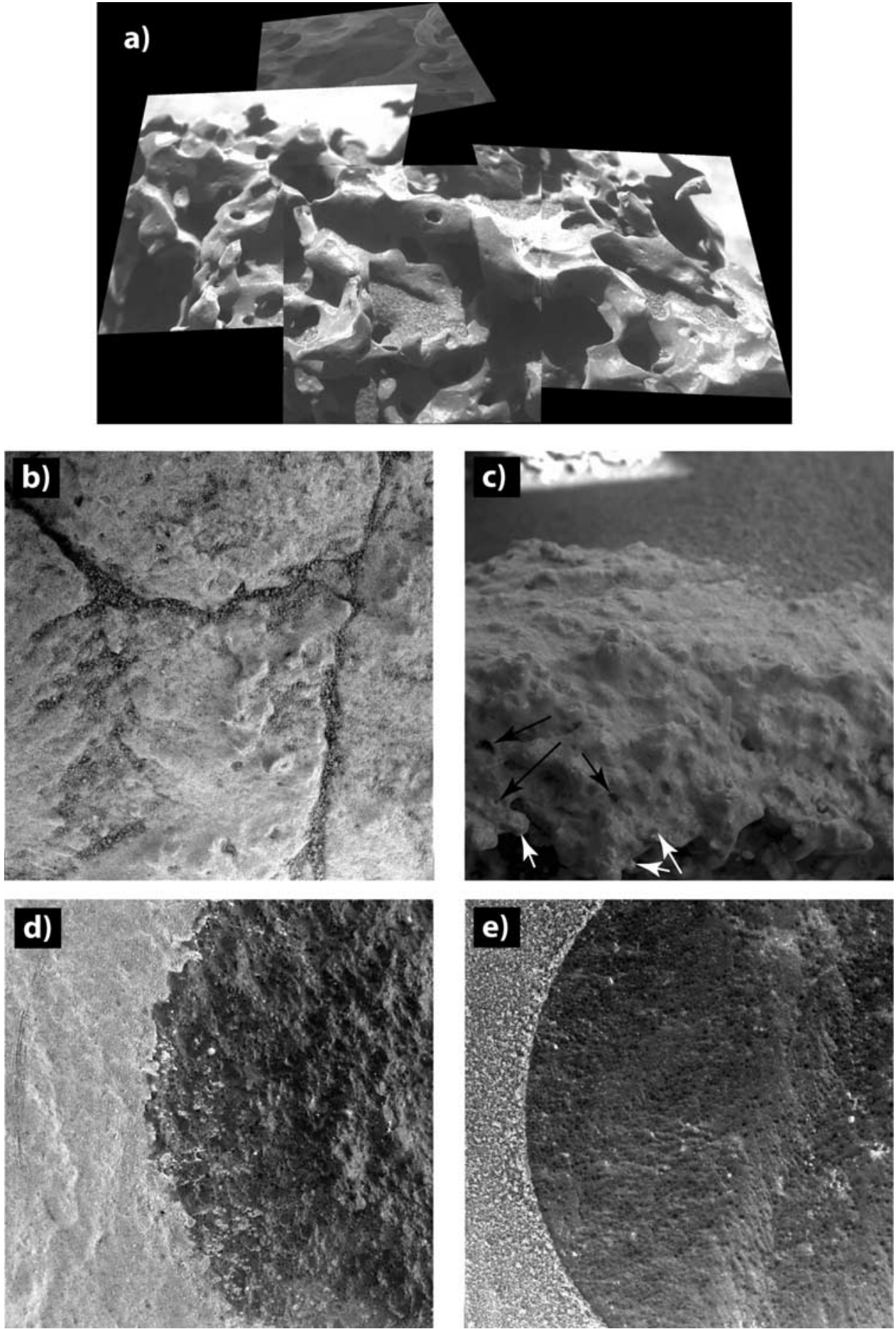

Figure 3. Microscopic Imager (MI) images of rock targets discussed in text. (a) Mosaic of the wind abraded vesicular basalt GongGong of the Irvine class. (b) The unbrushed rock target Barnhill_Ace that was examined by the IDD. Distorted square images in the mosaic are $31 \mathrm{~mm}$. (c) The lower, layered target Barnhill_Fastball that is a geochemical outlier in major elements. Note round clasts (white arrows) that may be accretionary lapilli and holes (black arrows) that may be vesicles. (d) Posey_Manager brushed target. Round to irregular 0.08 to $0.6 \mathrm{~mm}$ dark grains supported by a lighter-toned matrix are visible in the brushed portion. (e) The CoolPapaBell_Crawford target whose flat surface was well brushed, revealing small (ranging from 0.2 to $0.9 \mathrm{~mm}$ ) and more uniformly rounded grains than in the Posey target. Square images are $31 \mathrm{~mm}$ across. Square images (Figures $3 \mathrm{~b}-3 \mathrm{e}$ ) are $31 \mathrm{~mm}$ across. 


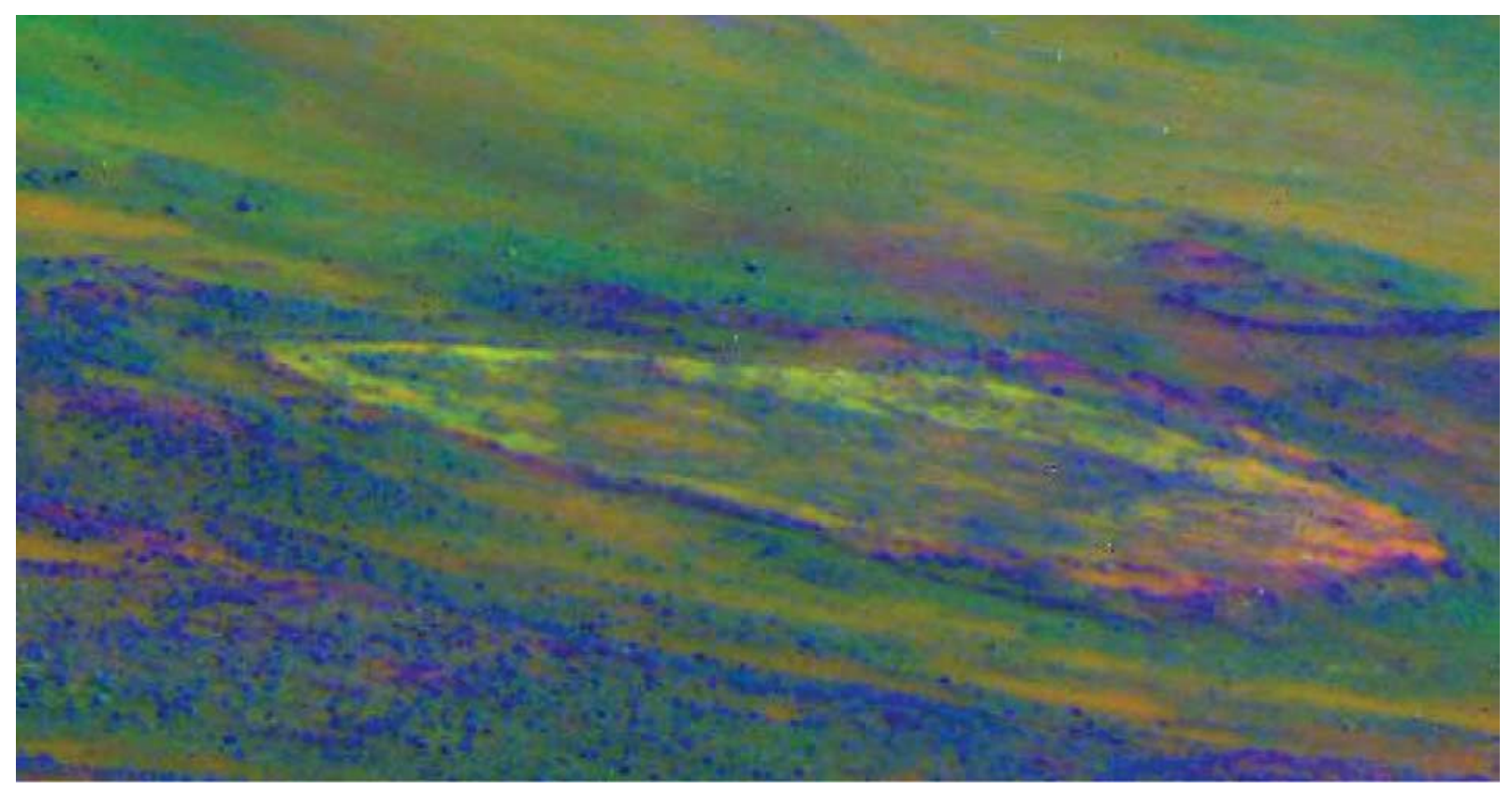

Figure 4. Pancam false-color representation of Home Plate acquired near the summit of Husband Hill on sol 595 (Pancam sequence P2282) demonstrating color differences around the rim of Home Plate that appear to be related to mineralogical differences [Farrand et al., 2008]. Red indicates 432 to $754 \mathrm{~nm}$ spectral slope; green indicates $432 \mathrm{~nm}$ reflectance; and blue indicates 754 to $1009 \mathrm{~nm}$ spectral slope.

The high degree of vesicularity of these basalts suggests that they are nearly in place and close to their vent [Crumpler et al., 2007]. It is unknown whether these vesicular basalts are broken up, jointed lava flows or pyroclastic scoria accumulations.

[9] Four Irvine class rocks have been examined by the IDD, including the massive Irvine on Husband Hill and the vesicular basalts Masada, GongGong (Figures 2a and 3a) and Esperanza in the Inner Basin (Figure 1). The RAT did not brush any Irvine class targets, but each analyzed spot was selected for minimal dust coverage and soil contamination. Microscopic images of wind-polished surfaces of Irvine reveal $\sim 1-5 \%$ light toned rectangular phenocrysts (likely plagioclase [McSween et al., 2006b]) within a dark groundmass.

\subsection{Home Plate}

[10] From near the summit of Husband Hill, Home Plate was observed to have color differences around its rim from west to east (Figure 4) [Farrand et al., 2008], a finding corroborated by later HiRISE orbital imaging. On closer examination, Home Plate was found to be a $\sim 1$ to $2 \mathrm{~m}$ tall, $\sim 80 \mathrm{~m}$ diameter light-toned, subcircular platform of finely laminated, massive, and cross-bedded dark-toned strata covered by lighter-toned dust [Squyres et al., 2007]. First approached at the northwest scarp, Spirit examined a $\sim 2 \mathrm{~m}$ tall section of Barnhill outcrop that comprises two units: a lower, laminated, coarser-grained unit and an upper finergrained cross-bedded unit (Figures $2 \mathrm{~b}$ and $2 \mathrm{c}$ ).

[11] The lower unit of Home Plate is $\sim 40 \mathrm{~cm}$ thick and laminated with apparent coarse grains at its base and a single massive $\sim 30 \mathrm{~cm}$ thick layer near the top. Texturally, the lower unit ranges from massive to knobby with subround protrusions (up to $2 \mathrm{~mm}$ ) that are potential accretion- ary lapilli. Layers are 1-2 $\mathrm{cm}$ thick alternate between coarse and fine grained (Figures $2 \mathrm{~b}$ and 2c), suggesting pulses in activity during deposition. The most conspicuous feature of the lower unit at Barnhill is an apparent bomb sag (Figure 2b), where layers deformed from the impact of a $\sim 3 \mathrm{~cm}$ clast. Small round holes $(0.3$ to $1.3 \mathrm{~mm})$ within the clastic rock may be vesicles caused by excess vapor during deposition. Because cohesion of the underlying material is required for deformation to occur, bomb sags and vesicles occur in wet phreatovolcanic deposits on Earth [Fisher and Schmincke, 1984]. Spirit was not able to examine the lowermost portion of the lower unit at the Barnhill outcrop because it was not reachable by the IDD but did analyze 2 targets in the upper part of the lower unit, including centimeter thick layers and the massive layer (Figures $2 \mathrm{~b}$, $2 \mathrm{c}, 3 \mathrm{~b}$, and $3 \mathrm{c})$. The RAT did not brush either Barnhill target. Posey is assumed to have fallen from between the Barnhill and CoolPapaBell rock targets.

[12] The upper unit of Home Plate consists of laminated, low- to high-angle (up to $30^{\circ}$ ) cross-bedded layers that dip $0-35^{\circ}$ toward the center of the structure [Squyres et al., 2007; K.W. Lewis et al., Structure and stratigraphy of Home Plate from the Spirit Mars Exploration Rover, submitted to Journal of Geophysical Research, 2008]. Spirit examined two rocks from the upper unit: the float rock Posey (Figures 2d and 3d) and CoolPapaBell (Figures 2e and $3 \mathrm{e})$ at the top of Home Plate. Posey was chosen for IDD analysis because its laminated, fine-grained texture is similar to the upper unit it is interpreted to have fallen from the upper northwest scarp. The RAT brush removed nearly all of the dust coatings on Posey and CoolPapaBell (Figures $3 c$ and $3 d$ ). MI images of the upper unit revealed round to irregular $<1 \mathrm{~mm}$ dark grains that are supported by a 
Table 1. Elemental Compositions of North Home Plate and Nearby Basalts ${ }^{\mathrm{a}}$

\begin{tabular}{|c|c|c|c|c|c|c|c|c|}
\hline & Irvine & Masada & Esperanza & $\begin{array}{c}\text { Barnhill_- } \\
\text { Ace }\end{array}$ & $\begin{array}{c}\text { Barnhill } \\
\text { Fastball }\end{array}$ & $\begin{array}{l}\text { Posey_ } \\
\text { Manager }\end{array}$ & $\begin{array}{l}\text { CoolPapa } \\
\text { Bell_Stars }\end{array}$ & $\begin{array}{c}\text { CoolPapa } \\
\text { Bell_Crawford }\end{array}$ \\
\hline Location & $\begin{array}{l}\text { Husband } \\
\text { Hill }\end{array}$ & Dead_Sea & Low Ridge & $\begin{array}{l}\text { Lower unit } \\
\text { North Home } \\
\text { Plate }\end{array}$ & $\begin{array}{l}\text { Lower unit } \\
\text { North Home } \\
\text { Plate }\end{array}$ & $\begin{array}{l}\text { Upper unit } \\
\text { North Home } \\
\text { Plate }\end{array}$ & $\begin{array}{c}\text { Top of North } \\
\text { Home } \\
\text { Plate }\end{array}$ & $\begin{array}{c}\text { Top of North } \\
\text { Home } \\
\text { Plate }\end{array}$ \\
\hline Class & Irvine & Irvine & Irvine & Barnhill & Barnhill & Barnhill & Barnhill & Barnhill \\
\hline Type & $\begin{array}{l}\text { Unbrushed } \\
\text { rock }\end{array}$ & $\begin{array}{l}\text { Unbrushed } \\
\text { vesicular } \\
\text { rock }\end{array}$ & $\begin{array}{l}\text { Unbrushed } \\
\text { vesicular } \\
\text { rock }\end{array}$ & $\begin{array}{l}\text { Unbrushed } \\
\text { rock }\end{array}$ & Unbrushed rock & Brushed rock & Brushed rock & Brushed rock \\
\hline Sol & 600 & 726 & 1055 & 749 & 750 & 754 & 763 & 764 \\
\hline $\mathrm{SiO}_{2}$ & $47.0(0.34)$ & $46.5(0.6)$ & $47.9(0.5)$ & $45.2(0.3)$ & $45.3(0.3)$ & $45.4(0.4)$ & $46.0(0.3)$ & $46.6(0.4)$ \\
\hline $\mathrm{TiO}_{2}$ & $1.06(0.06)$ & $0.74(0.10)$ & $1.05(0.08)$ & $0.74(0.06)$ & $0.67(0.06)$ & $1.01(0.06)$ & $0.93(0.06)$ & $1.11(0.07)$ \\
\hline $\mathrm{Al}_{2} \mathrm{O}_{3}$ & $8.29(0.09)$ & $9.52(0.21)$ & $8.40(0.13)$ & $8.91(0.08)$ & $7.85(0.08)$ & $9.31(0.10)$ & $9.30(0.09)$ & $9.98(0.12)$ \\
\hline $\mathrm{FeO}^{*}$ & $19.2(0.08)$ & $17.2(0.16)$ & $20.2(0.15$ & $17.7(0.06)$ & $17.8(0.07)$ & $15.4(0.09)$ & $15.4(0.09)$ & $15.4(0.09)$ \\
\hline $\mathrm{MnO}$ & $0.36(0.01)$ & $0.36(0.03)$ & $0.38(0.01)$ & $0.39(0.01)$ & $0.47(0.01)$ & $0.32(0.01)$ & $0.31(0.01)$ & $0.29(0.01)$ \\
\hline $\mathrm{MgO}$ & $10.63(0.12)$ & $9.00(0.24)$ & $8.45(0.13)$ & $9.19(0.09)$ & $11.99(0.11)$ & $9.48(0.10)$ & $9.59(0.09)$ & $10.26(0.12)$ \\
\hline $\mathrm{CaO}$ & $6.03(0.04)$ & $6.05(0.11)$ & $5.57(0.06)$ & $6.07(0.04)$ & $5.80(0.04)$ & $6.65(0.04)$ & $6.50(0.04)$ & $6.74(0.05)$ \\
\hline $\mathrm{Na}_{2} \mathrm{O}$ & $2.68(0.26)$ & $3.10(0.42)$ & $3.40(0.25)$ & $3.10(0.17)$ & $2.35(0.17)$ & $3.50(3.25)$ & $3.25(0.18)$ & $3.36(0.21)$ \\
\hline $\mathrm{K}_{2} \mathrm{O}$ & $0.68(0.06)$ & $0.53(0.08)$ & $0.52(0.06)$ & $0.32(0.05)$ & $0.23(0.05)$ & $0.42(0.06)$ & $0.21(0.05)$ & $0.32(0.06)$ \\
\hline $\mathrm{P}_{2} \mathrm{O}_{5}$ & $0.97(007)$ & $0.90(0.11)$ & $0.91(0.8)$ & $0.87(0.07)$ & $0.79(0.07)$ & $1.37(0.07)$ & $1.12(0.07)$ & $1.27(0.08)$ \\
\hline $\mathrm{Cr}_{2} \mathrm{O}_{3}$ & $0.20(0.03)$ & $0.35(0.06)$ & $0.20(0.03)$ & $0.45(0.03)$ & $0.49(0.03)$ & $0.32(0.03)$ & $0.39(0.03)$ & $0.34(0.03)$ \\
\hline $\mathrm{SO}_{3}$ & $2.37(0.03)$ & $5.00(0.16)$ & $2.36(0.06)$ & $5.67(0.06)$ & $4.63(0.06)$ & $4.81(0.06)$ & $3.75(0.05)$ & $2.91(0.05)$ \\
\hline $\mathrm{Cl}$ & $0.45(0.01)$ & $0.57(0.04)$ & $0.47(0.02)$ & $1.31(0.02)$ & $1.57(0.02)$ & $1.94(0.02)$ & $1.74(0.02)$ & $1.35(0.02)$ \\
\hline Ni (ppm) & $289(37)$ & 459 (100) & $395(54)$ & $317(35)$ & $352(0.39)$ & $379(35)$ & 318 (37) & $297(40)$ \\
\hline $\mathrm{Zn}(\mathrm{ppm})$ & $230(11)$ & $317(48)$ & $368(22)$ & 400 (11) & 415 (14) & 407 (11) & 422 (13) & 314 (14) \\
\hline Ge (ppm) & $14(6)$ & - & 19 (12) & $68(6)$ & $71(8)$ & $34(5)$ & $27(7)$ & $16(8)$ \\
\hline $\mathrm{Br}(\mathrm{ppm})$ & $6(13)$ & $64(27)$ & $181(23)$ & $475(17)$ & $370(18)$ & $181(15)$ & $203(16)$ & $91(15)$ \\
\hline
\end{tabular}

${ }^{a}$ Compositions are presented as wt \%, unless noted otherwise. Values in parentheses are $2 \sigma$ errors. $\mathrm{FeO}^{*}$ concentrations are total $\mathrm{Fe}$ as $\mathrm{FeO}$. The valence state of $\mathrm{S}$ is unknown and is reported here as $\mathrm{SO}_{3}$.

lighter-toned matrix (Figures 3c and 3d). The high degree of rounding of clasts and cross bedding in the upper unit suggests that the deposit may have been reworked by eolian processes [Squyres et al., 2007; Lewis et al., submitted manuscript, 2008].

\subsection{Other Rocks and Soils}

[13] For comparison, this paper also references other classes of rocks and soils that were examined by Spirit earlier in the mission. The Adirondack class basalts make up the plains surrounding the Columbia Hills [e.g., Squyres et al., 2004a; McSween et al., 2006a] and have been observed as float rocks throughout the Columbia Hills [Ruff et al., 2006]. The highly altered, Cl-rich, clastic Clovis class was discovered at West Spur, a low hill west of Husband Hill [Gellert et al., 2006; Ming et al., 2006; Squyres et al., 2006]. The Wishstone and Watchtower classes of Husband Hill are high Ti and $\mathrm{P}$ clastic rocks [e.g., Squyres et al., 2006; Hurowitz et al., 2006b; Ming et al., manuscript in preparation, 2008]. The Algonquin class is a compositionally and texturally diverse group of olivine-rich clastic rounded boulders and outcrops that were found on the southeastern rib of Husband Hill known as Haskin Ridge [Mittlefehldt et al., 2006; Ming et al., manuscript in preparation, 2008].

[14] An important group of soils are the white to yellow Paso Robles sulfate soils (Figure 2a). These soils include Paso Robles found on the northwest flank of Husband Hill [Ming et al., 2006; Yen et al., 2008], and at Dead_Sea (Arad target, Figures 1 and 2a) and Tyrone [Yen et al., 2008; Johnson et al., 2007; A. Wang et al., Distribution and origin of light-toned salty soils discovered by the Mars Exploration rover Spirit in Gusev Crater, manuscript in preparation, $2008]$ in the Inner Basin. At each of these locations, the rover's wheel unearthed white to light yellow friable material beneath a surface layer of reddish brown soil. The distribution of these soils is unknown and may be extensive in the low areas of the Inner Basin.

\section{Compositional and Mineralogical Characteristics}

[15] The classification of the diverse rocks found in Gusev Crater is based on chemical compositions acquired

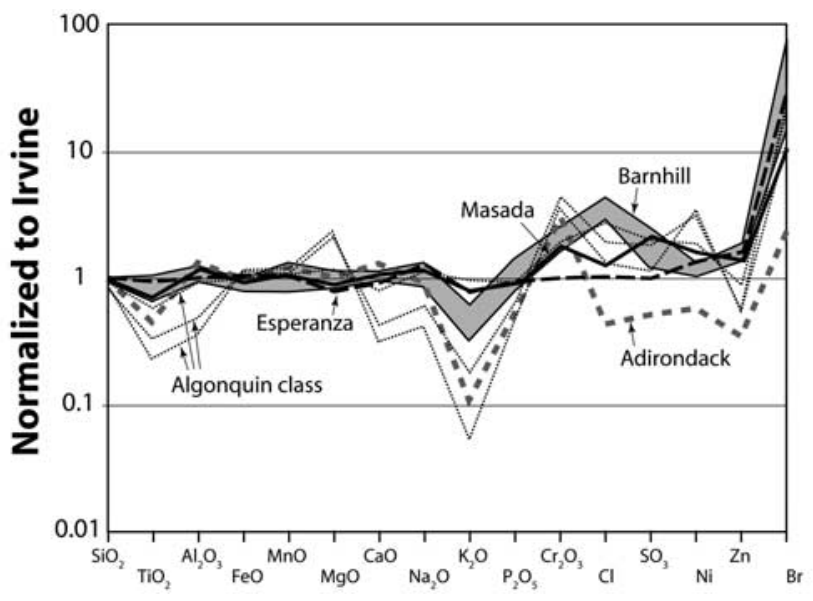

Figure 5. Element abundance diagram normalized to the rock Irvine for the Barnhill class and the rock targets Adirondack, Masada, Esperanza, and the brushed analyses for the Algonquin class rocks Seminole, Algonquin, and Comanche. Later discussions make use of Masada as a reference because it is most like the Barnhill class targets in nonmobile elements. 
by APXS analysis. Classes are typically named for the first rock examined of that group [Squyres et al., 2006; Ming et al., manuscript in preparation, 2008]. The Barnhill and Irvine rocks are similar in major elements; both classes vary from 45 to 47 wt $\% \mathrm{SiO}_{2}$ and encompass narrow ranges in composition (Table 1 and Figures 5 and 6), suggesting derivation from a similar source. There are differences in volatile and minor elements between the Irvine and Barnhill rocks that warrant their classification into separate groups. Differences in texture and mineralogy also exist between the Irvine and Barnhill groups that attest to different emplacement, cooling, and alteration histories. We here summarize APXS, Mössbauer, and Mini-TES results for these rock classes and Pancam multispectral data for the Barnhill class.

\subsection{Irvine Basalts}

\subsubsection{APXS Results}

[16] The Irvine class represents a distinct unaltered basaltic magma type in the Columbia Hills. Relative to most terrestrial basalts, such as mid-ocean ridge basalts, Irvine basalts are rich in $\mathrm{FeO}^{*}(15-20 \mathrm{wt} \%)$ and generally poor in $\mathrm{Al}_{2} \mathrm{O}_{3}$ (8-10 wt \%). Irvine basalts have similar $\mathrm{SiO}_{2}$ and $\mathrm{MgO}$ concentrations to the Adirondack basalts of the Gusev Plains [Squyres et al., 2006; Gellert et al., 2006] but range to higher concentrations of alkali elements than Adirondack class basalts (e.g., $2.7-3.8$ versus $2.4-2.8$ wt $\% \mathrm{Na}_{2} \mathrm{O}$ ). Irvine basalts also have higher concentrations of some minor and trace elements than Adirondack basalts, including $\mathrm{TiO}_{2}, \mathrm{P}_{2} \mathrm{O}_{5}, \mathrm{Ni}$, and $\mathrm{Zn}$.

[17] Compositional differences among the few Irvine basalts that were examined by APXS (Irvine, Masada, and Esperanza) can be accounted for by soil contamination and minor removal of Fe-bearing phases identified by Mössbauer. Among the Irvine class, analytical errors are greatest for the target Masada because tight time constraints limited the APXS observation of Masada to 30 min (Table 1). Masada has higher $\mathrm{SO}_{3}, \mathrm{Cr}_{2} \mathrm{O}_{3}$, and $\mathrm{Ni}$ than Irvine (Table 1) suggesting some soil contamination, possibly trapped within its vesicles. Masada also has lower $\mathrm{FeO}^{*}$ and $\mathrm{TiO}_{2}$ concentrations (Figure 5 and Table 1) than the rock Irvine and this may have been caused by minor fractional crystallization of Timagnetite, a mineral commonly identified by Mössbauer in these rocks. Esperanza is distinct from other Irvine basalts by its higher $\mathrm{SiO}_{2}$ and lower $\mathrm{MgO}$ (Table 1 and Figure 6a) than either Irvine or Masada and its composition is consistent with loss of $5-10 \%$ olivine by fractional crystallization or dissolution by chemical weathering. Esperanza also has significantly higher $\mathrm{Br}(181 \mathrm{ppm})$ than other Irvine basalts (Figures 6 and 7).

\subsubsection{Mössbauer Spectrometer Results}

[18] Irvine class basalts analyzed by Mössbauer spectrometer include Irvine, Esperanza, and GongGong (Table 2) (R.V. Morris et al., Iron mineralogy and queous alteration from Husband Hill through Home Plate at Gusev Crater, Mars: Results from the Moessbauer instrument on the Spirit Mars Exploration Rover, submitted to Journal of Geophysical Research, 2008). The examination of Esperanza was a shortened 25-h integration. Although no APXS analysis was performed on the vesicular GongGong (Figure 3a), it is classified here as a member of the Irvine class because of its proximity to Masada and has $\mathrm{Fe}$ mineralogy is like that of Irvine. A significant amount of the $\mathrm{Fe}$ in Irvine basalts is held in magnetite and pyroxene (36-54\% and $33-46 \%$, respectively). Only $4-9 \%$ of the $\mathrm{Fe}$ in the Irvine class is in olivine and less than $10 \%$ of the $\mathrm{Fe}$ is contained in nanophase oxide and hematite.

\subsubsection{Mini-TES Results}

[19] Thermal infrared spectra from Mini-TES $(\sim 5-25 \mu \mathrm{m}$, $\sim 2000-400 \mathrm{~cm}^{-1}$ ) serve to establish the distribution and bulk mineralogy of the rocks and soils encountered along the rover's traverse. A transition from the olivine-dominant Algonquin class rocks of the lower Haskin Ridge to pyroxene-dominant Irvine class rocks was first observed on sol 723 at the north end of Lorre Ridge (Figure 1). The spectral characteristics of a vesicular float rock dubbed Ein Gedix clearly depart from the clastic Algonquin class rocks and strongly resemble those of the average Irvine class rocks first identified with Mini-TES on top of Husband Hill (Figure 8). A second example of Irvine-like spectral character was encountered some $200 \mathrm{~m}$ further south on sol 736 in a more massive rock dubbed Luo $\mathrm{Zu}$ (Figure 8) that is similar to texture to original Irvine target. These two rocks thus demonstrate that Irvine class rocks have similar mineralogy despite significant variations in texture.

[20] A total of 46 rocks with Irvine class spectral character have been encountered (Figure 9a), mostly along the eastern edge of Home Plate and Low Ridge to the south. Of these, only Esperanza has a full complement of measurements from all the Athena instruments. Masada and GongGong were not observed because they were well below the size of the Mini-TES field of view. Deconvolution of the Esperanza spectrum into constituent phases provides a much better fit (Figure 9b) than that obtained from the original Irvine class rocks [McSween et al., 2006b] probably due to more favorable measurement conditions. Pyroxene is the dominant component at $\sim 35 \%$ abundance with pigeonite at $\sim 25 \%$ of the total (Table 3 ). A sulfate component approaching $20 \%$ abundance is required to achieve a good fit, similar to most of the rocks measured by Mini-TES

\footnotetext{
Figure 6. $\mathrm{SiO}_{2}$ variation diagrams for main rock types discussed in text. Symbols correspond to target type as RAT abraded (R, black box), brushed (B, colored box), or unbrushed (U, no box). The outlier Barnhill_Fastball is indicated. The Irvine class rocks Irvine (Irv), Masada (Mas), and Esperanza are indicated to show variation among the unaltered basalt near equivalent to the Barnhill class. Fields enclose undisturbed Gusev soil analyses until sol 805 [Gellert et al., 2004, 2006]. (a) $\mathrm{MgO}$ versus $\mathrm{SiO}_{2}$ and (b) $\mathrm{Al}_{2} \mathrm{O}_{3}$ versus $\mathrm{SiO}_{2}$ plots indicate linear variations among the Barnhill targets of increasing $\mathrm{SiO}_{2}, \mathrm{MgO}$, and $\mathrm{Al}_{2} \mathrm{O}_{3}$ that corresponds with stratigraphic height. Among the alkalis, Barnhill targets have similar $\mathrm{N}_{2} \mathrm{O}$ to Irvine basalts as shown for (c) $\mathrm{Na}_{2} \mathrm{O}$ versus $\mathrm{SiO}_{2}$, but lower $\mathrm{K}_{2} \mathrm{O}$ as shown for (d) $\mathrm{K}_{2} \mathrm{O}$ versus $\mathrm{SiO}_{2}$. (e) Plot of $\mathrm{Cl}$ versus $\mathrm{SiO}_{2}$ demonstrates the high $\mathrm{Cl}$ in the Barnhill class relative to unaltered basalts and undisturbed soils.
} 
throughout the Columbia Hills [Ruff et al., 2006]. The significant proportion of sulfate is unsubstantiated by APXS and $\mathrm{MB}$ data sets and likely represents a surface coating on the unbrushed surface. A basaltic glass phase of $\sim 15 \%$ and plagioclase and olivine at $\sim 10 \%$ each are required for a good fit. Among the 13 secondary silicate phases included in the deconvolution end-member set, $\sim 10 \%$ saponite improved the fit and is an indication of minor alteration perhaps consistent with a coating.

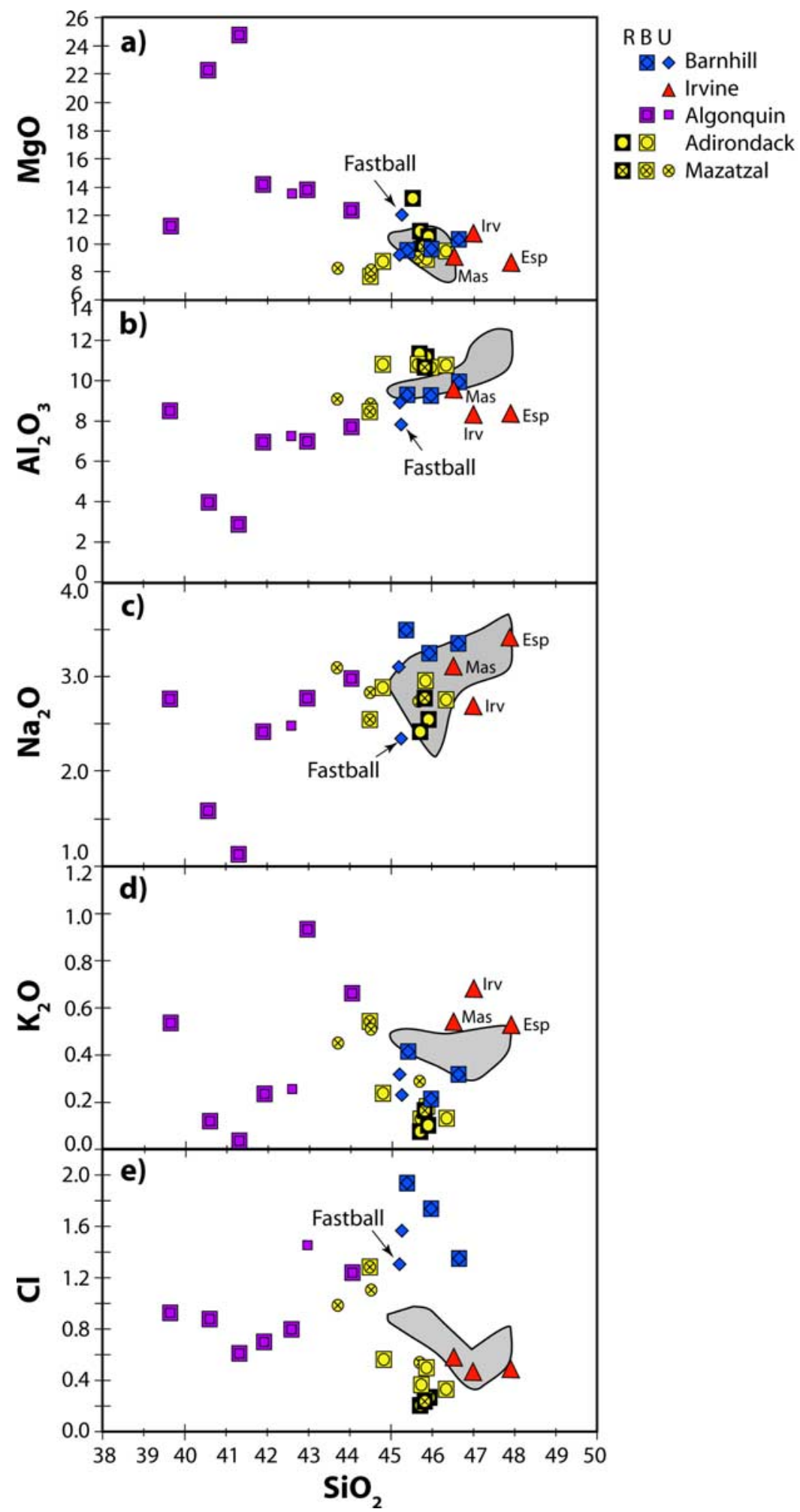

Figure 6 


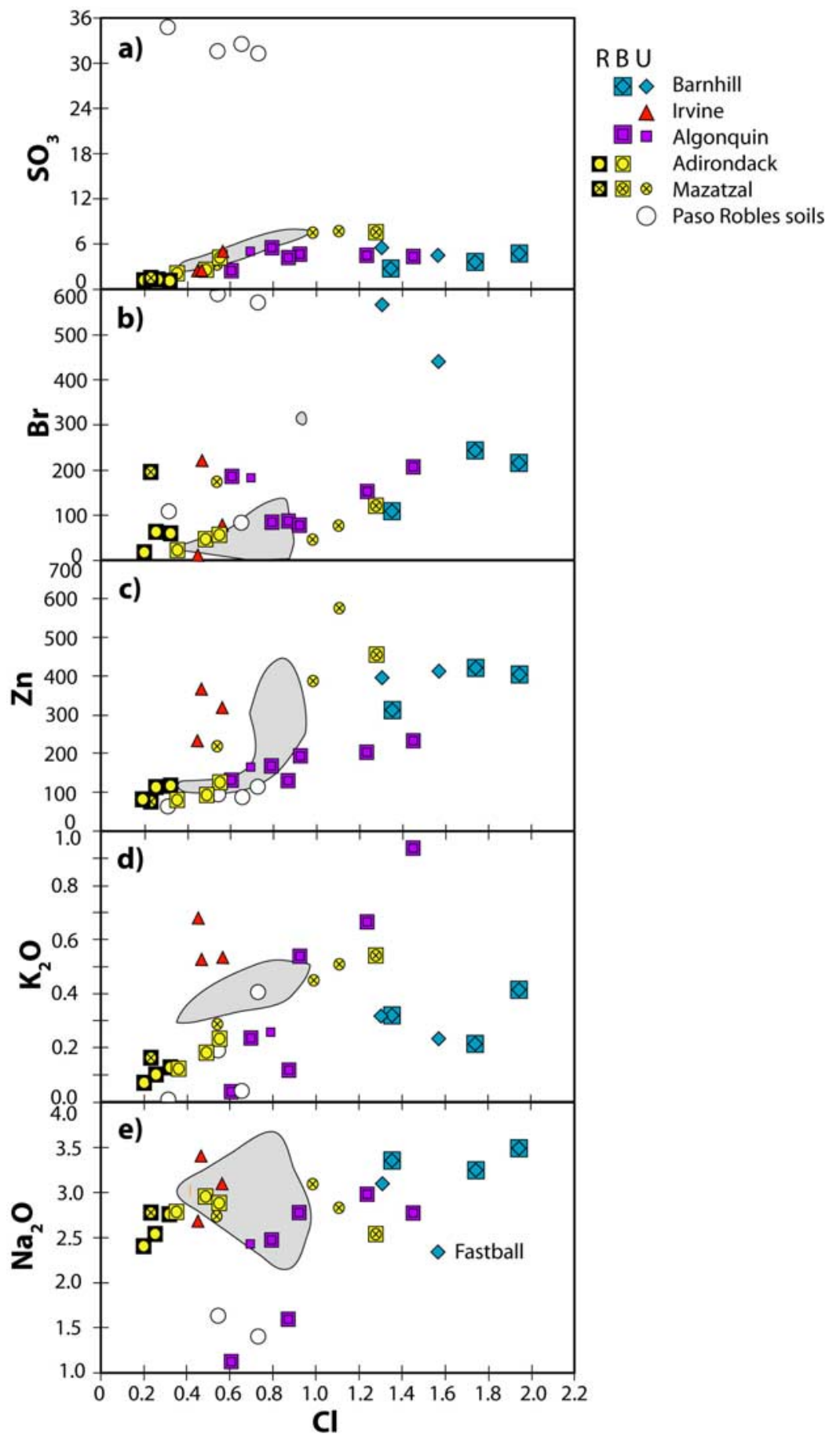

Figure 7. $\mathrm{Cl}$ variation diagrams for main rock types and they Paso Roble sulfate-rich soils. (a) $\mathrm{SO}_{3}$ versus $\mathrm{Cl}$ reveals the high $\mathrm{Cl}$ character of the Barnhill class with comparable $\mathrm{SO}_{3}$ to the relatively unaltered Irvine basalts, (b) $\mathrm{Br}$ versus $\mathrm{Cl}$, (c) $\mathrm{Zn}$ versus $\mathrm{Cl}$, (d) $\mathrm{K}_{2} \mathrm{O}$ versus $\mathrm{Cl}$, and (e) $\mathrm{Na}_{2} \mathrm{O}$ versus $\mathrm{Cl}$. Symbols correspond to target type as RAT abraded (R, black box), brushed (B, colored box), or unbrushed (U, no box). Fields enclose undisturbed soil analyses from Gusev Crater until sol 805 [Gellert et al., 2004, 2006].

\subsection{Barnhill Class of Home Plate}

\subsubsection{APXS Results: Major Elements}

[21] Although Barnhill class rocks have higher concentrations of some volatile elements, they are basaltic and rich in $\mathrm{Na}_{2} \mathrm{O}$ like Irvine class rocks (Figures 5, 6e, and 7). In an
Irvine-normalized element abundance diagram (Figure 5), concentrations of most nonvolatile elements $\left(\mathrm{SiO}_{2}, \mathrm{Al}_{2} \mathrm{O}_{3}\right.$, $\mathrm{CaO}, \mathrm{FeO}^{*}, \mathrm{TiO}_{2}$ ) center at or near 1 , excepting $\mathrm{K}_{2} \mathrm{O}$ and $\mathrm{Cr}_{2} \mathrm{O}_{3}$. An outlier among the Barnhill class is the stratigraphically lowest target Barnhill_Fastball, which has lower 
Table 2. Mössbauer Areas for Component Subspectra, $\mathrm{Fe}^{3+} / \mathrm{Fe}_{\mathrm{Total}}$, and Temperature Measurement Interval ${ }^{\mathrm{a}}$

\begin{tabular}{|c|c|c|c|c|c|c|}
\hline & Irvine & GongGong & Esperanza & Barnhill_Ace & Posey_Manager & CoolPapaBell_Stars \\
\hline Class & Irvine & Irvine & Irvine & Barnhill & Barnhill & Barnhill \\
\hline Sol & 602 & 737 & 1056 & 748 & 754 & 762 \\
\hline $\mathrm{Ol} \%$ & 9 & 6 & 4 & 18 & 17 & 17 \\
\hline Px \% & 46 & 33 & 45 & 22 & 23 & 23 \\
\hline npOx \% & 6 & 5 & 4 & 29 & 27 & 29 \\
\hline Mt $\%$ & 36 & 54 & 45 & 24 & 31 & 28 \\
\hline $\mathrm{Hm} \%$ & 3 & 2 & 1 & 7 & 3 & 3 \\
\hline Sum \% & 100 & 100 & 100 & 100 & 100 & 100 \\
\hline $\mathrm{Fe}^{3+} / \mathrm{Fe}_{\text {Total }}$ & 0.35 & 0.45 & 0.40 & 0.53 & 0.53 & 0.52 \\
\hline
\end{tabular}

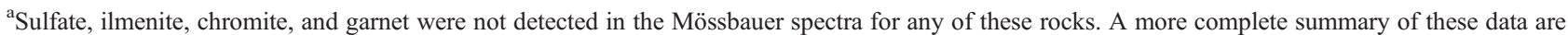
presented by Morris et al. (submitted manuscript, 2008). Uncertainty in component subspectra area is $\pm 2 \%$ absolute. Uncertainty in $\mathrm{Fe}^{3+} / \mathrm{Fe}_{\mathrm{T}}$ is \pm 0.03 .

$\mathrm{Na}_{2} \mathrm{O}$ and $\mathrm{Al}_{2} \mathrm{O}_{3}$ and higher $\mathrm{MgO}$ and $\mathrm{FeO}^{*}$ (Figure 6). In spite of the small compositional range, systematic variations exist within the Barnhill class that correlate with stratigraphy. Within the $<2 \mathrm{~m}$ distance from Barnhill Fastball to CoolPapaBell, $\mathrm{SiO}_{2}, \mathrm{Al}_{2} \mathrm{O}_{3}, \mathrm{CaO}$, and $\mathrm{TiO}_{2}$ increase and $\mathrm{FeO} * \mathrm{Cr}_{2} \mathrm{O}_{3}$, and $\mathrm{MnO}$ form near-linear trends and decrease up section (Figures 6a and 6b). Excluding Fastball, the $\mathrm{MgO}$ also increases up section. These major elements are not easily affected by chemical weathering [Hurowitz et al., 2006a] and probably reflect a primary process, such as igneous fractional crystallization or mixing, perhaps analogous to ash flow tuffs erupted from a zoned magma chamber on Earth [Hildreth, 1981].

\subsubsection{APXS Results: Volatile Elements}

[22] Barnhill class layered rocks have higher concentrations of halogen $(\mathrm{Cl}$ and $\mathrm{Br})$ and volatile siderophile $(\mathrm{Ge}$ and $\mathrm{Zn}$ ) elements than Irvine class rocks (Table 1 and Figures 5 to 7) or any other unaltered basalts in Gusev Crater. Concentrations of $\mathrm{Cl}$ in the Barnhill class are 3-4 times greater than in Irvine (Table 1). The volatile metal germanium has only been detected in four distinct rock groups on Mars by the Spirit and Opportunity rovers, but Ge concentrations range from 16 to $71 \mathrm{ppm}$ in the Barnhill class. Concentrations of $\mathrm{Br}$ are most variable among the Barnhill class and of the unbrushed targets, $\mathrm{Br}$ concentrations are among the highest so far observed in Gusev Crater. Variable concentrations of $\mathrm{SO}_{3}\left(2.9\right.$ to $5.7 \mathrm{wt} \% \mathrm{SO}_{3}$; Table 1) in the Barnhill class are comparable to the Irvine class and other unaltered basalts in Gusev Crater (Figure 7a). The S-rich environment at the surface of Mars makes it likely that surface soil and (or) dust contamination caused the variable $\mathrm{S}$ in the Barnhill class.

[23] There are no apparent correlations between the $\mathrm{Cl}$, $\mathrm{Br}$, or $\mathrm{Zn}$ and other mobile elements, such as $\mathrm{SO}_{3}, \mathrm{~K}_{2} \mathrm{O}$ or $\mathrm{Na}_{2} \mathrm{O}$ (Figure 7). There are also no apparent stratigraphic correlations in $\mathrm{Zn}, \mathrm{Ge}, \mathrm{Cl}, \mathrm{Br}$ or alkali elements like those observed in major elements (Figure 6e), indicating that the process responsible for the stratigraphic variations in nonvolatile elements is independent of volatile element enrichment at Home Plate.

\subsubsection{Mössbauer Spectrometer Results}

[24] In comparison to the Irvine class, the Barnhill class contains greater proportions of np ox (26-29\%) and olivine (17-18\%; Table 2) (Morris et al., submitted manuscript, 2008). Other Fe-bearing minerals include pyroxene, magnetite, and hematite. The larger fraction of $\mathrm{Fe}^{3+}$-bearing phases in the Barnhill class relative to Irvine rocks yields a greater $\mathrm{Fe}^{3+} / \mathrm{Fe}_{\text {total }}$ than Irvine class basalts $(0.52-0.53$ versus 0.35-0.45) (Morris et al., submitted manuscript, 2008). CIPW norms (Table 4) using the $\mathrm{Fe}^{3+} / \mathrm{Fe}_{\text {total }}$ determinations by Mössbauer indicate that the Barnhill class and two Irvine class rocks, Masada and Esperanza are quartz normative. Modest proportions of olivine in the Barnhill class rocks (Table 2) suggest that they do not contain an equilibrium assemblage.

\subsubsection{Visible and Near-Infrared Multispectral \\ Properties}

[25] Layered rocks at Home Plate examined during the initial survey displayed two different types of spectra (Figure 10). Undisturbed rocks with surfaces swept clean by the wind as well as the Posey RAT brush spot were characterized by a broad relative reflectance maximum peaking between 750 and $800 \mathrm{~nm}$. These rocks display either reflectance absorption at $\sim 950$ or a flat to somewhat lower reflectance beyond $1 \mu \mathrm{m}$. The CoolPapaBell (Stars and Crawford) RAT brush spots had a narrower relative reflectance maximum displaced to shorter wavelengths at $\sim 675-750 \mathrm{~nm}$. The absorption feature that is most evident in the Stars and Crawford RAT brush spot spectra and the relative reflectance maximum at $\sim 675-750 \mathrm{~nm}$ is consis-

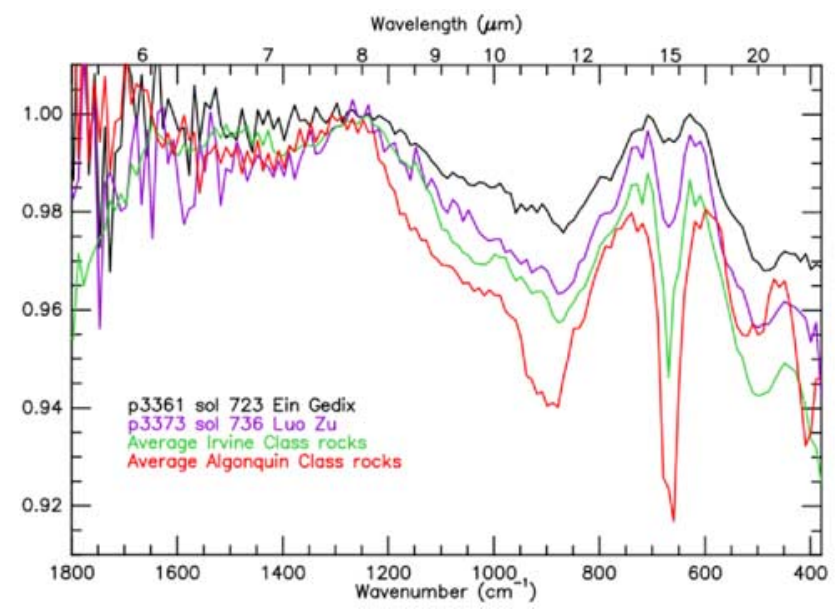

Figure 8. Mini-TES spectra of the first two examples of Irvine class rocks encountered en route to Home Plate. They are notably similar to the original Irvine class rocks found on top of Husband Hill and dissimilar to the Algonquin class rocks of lower Haskin Ridge. Note that the spectra at wave numbers $>1500$ and $600-800 \mathrm{~cm}^{-1}$ are influenced by atmospheric absorption. 

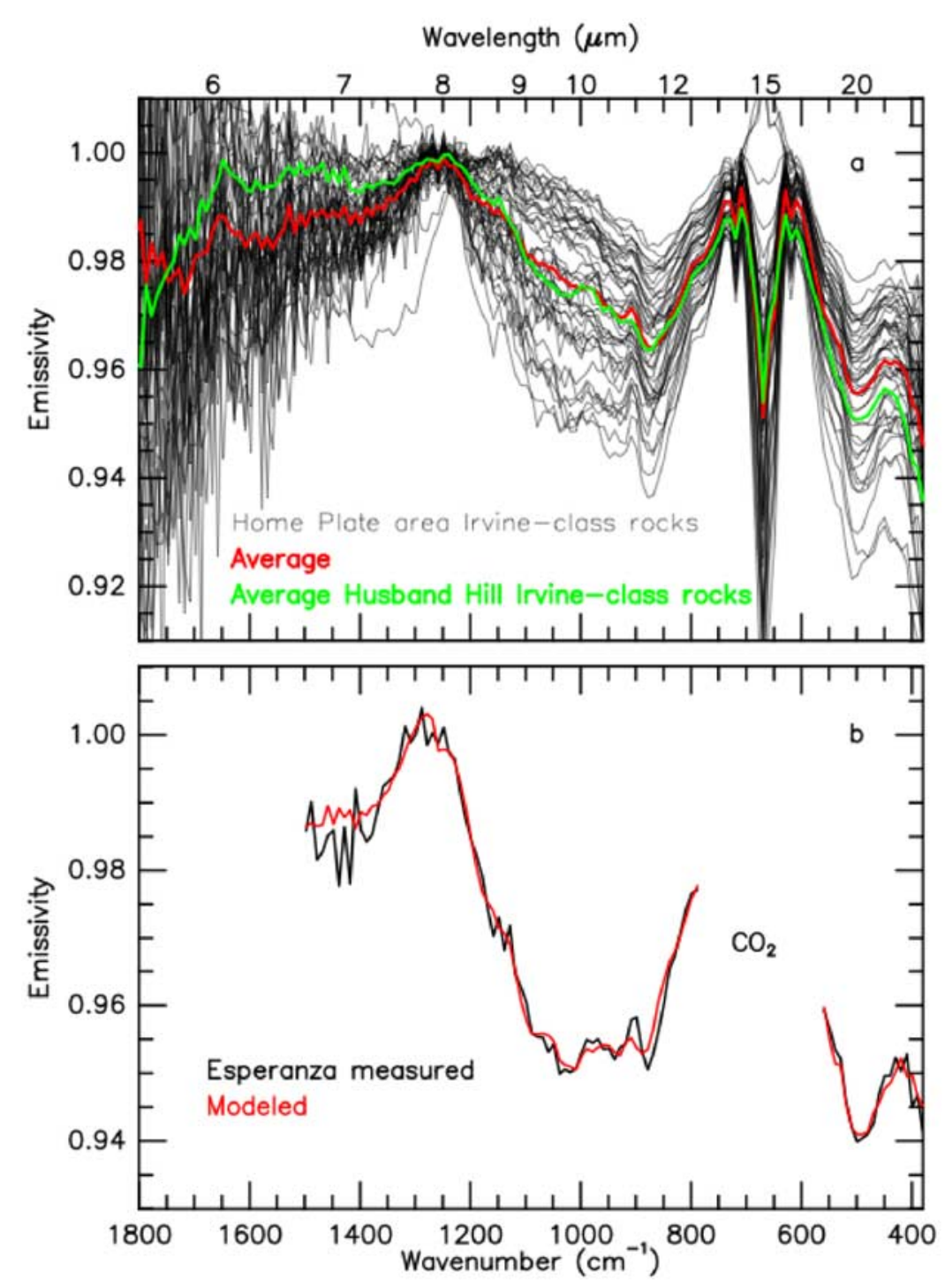

Figure 9. (a) Mini-TES spectra of 46 rocks encountered on or near Home Plate that on average, strongly resemble the original Irvine class rocks found on top of Husband Hill. (b) Esperanza was the subject of a full instrument campaign. Spectral deconvolution provides a good model fit with the component phases shown in Table 3.

tent with the presence of a low-Ca pyroxene. The suppression of reflectance in the $1009 \mathrm{~nm}$ band in the Posey spectrum could be caused by a higher fraction of opaque minerals and is supported by Mössbauer spectrometer results (section 3.2.3) (Morris et al., submitted manuscript, 2008), indicating marginally higher amounts of magnetite in Posey than in Stars (Table 2).

\subsubsection{Mini-TES Results}

[26] The layered rocks of Home Plate are spectrally distinct from the Irvine class rocks and all other rocks encountered previously. They most resemble the glassy rocks found on the West Spur of the Columbia Hills known as Clovis Class and Watchtower Class from the north flank of Husband Hill [Ruff et al., 2006; Squyres et al., 2006]. The coarsely bedded lower unit at the Barnhill outcrop was significantly contaminated with soil such that no exposures of outcrop large enough to fill the Mini-TES field of view were available. Two displaced outcrop pieces from the
Table 3. Mini-TES Spectral Deconvolution Results ${ }^{\mathrm{a}}$

\begin{tabular}{|c|c|}
\hline & Percentage \\
\hline \multicolumn{2}{|c|}{ Irvine Class } \\
\hline Pyroxene (Pigeonite) & $35(25)$ \\
\hline Sulfate & 20 \\
\hline Basaltic glass & 15 \\
\hline Plagioclase & 10 \\
\hline Olivine & 10 \\
\hline Secondary silicate & 10 \\
\hline \multicolumn{2}{|c|}{ Barnhill Class } \\
\hline Basaltic glass & 40 \\
\hline Secondary silicate & 25 \\
\hline Plagioclase & 10 \\
\hline Olivine & 10 \\
\hline Pyroxene & 5 \\
\hline Sulfate & 5 \\
\hline
\end{tabular}

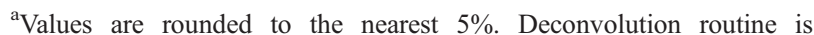
presented by Ruff et al. [2006] with a mirror dust correction by Smith et al. [2006]. 
Table 4. CIPW Norm Calculations for Irvine and Barnhill Class Rocks ${ }^{\mathrm{a}}$

\begin{tabular}{|c|c|c|c|c|c|c|}
\hline & Irvine & Masada & Esperanza & Barnhill_Ace & Posey & $\begin{array}{c}\text { JamesCool } \\
\text { PapaBell_Stars } \\
\end{array}$ \\
\hline $\mathrm{Fe}^{3+} / \mathrm{Fe}_{\mathrm{T}}$ & 0.35 & 0.45 & 0.4 & 0.53 & 0.51 & 0.52 \\
\hline Quartz & 0 & 2.42 & 2.39 & 3.56 & 0.81 & 1.74 \\
\hline Plagioclase & 30.34 & 37.54 & 33.97 & 36.96 & 39.45 & 39.99 \\
\hline Orthoclase & 4.02 & 3.31 & 3.07 & 2.01 & 2.6 & 1.95 \\
\hline Diopside & 11.67 & 10.72 & 11.85 & 11.83 & 12.98 & 10.54 \\
\hline Hypersthene & 36.15 & 28.14 & 28.91 & 24.67 & 24.43 & 26.19 \\
\hline Olivine & 0.11 & 0 & 0 & 0 & 0 & 0 \\
\hline Ilmenite & 2.01 & 1.48 & 1.99 & 1.48 & 2.03 & 2.17 \\
\hline Magnetite & 10.83 & 13.09 & 13.02 & 16.02 & 13.4 & 13.28 \\
\hline Hematite & 0 & 0 & 0 & 0 & 0 & 0 \\
\hline Apatite & 2.11 & 2.18 & 2.11 & 2.13 & 3.06 & 3.06 \\
\hline Zircon & 0.07 & 0.06 & 0.07 & 0.07 & 0.07 & 0.06 \\
\hline Chromite & 0.43 & 0.78 & 0.43 & 1.02 & 0.74 & 0.75 \\
\hline $\mathrm{Na}_{2} \mathrm{SO}_{4}$ & 0.53 & 0.53 & 0.53 & 0.53 & 0.53 & 0.53 \\
\hline
\end{tabular}

${ }^{\mathrm{a}}$ In normative wt $\%$. CIPW norms were calculated with $0 \% \mathrm{Cl}$ and $0.3 \% \mathrm{SO}_{3}$ as done by McSween et al. [2006a]. Norm technique was developed by Cross, Iddings, Pirsson, and Washington (CIPW [Johannsen, 1931]), but these norms were calculated using a spreadsheet provided by K. Hollocher (Calculation of a CIPW norm from a bulk chemical analysis, 2007, available at http://www.union.edu/PUBLIC/GEODEPT/COURSES/petrology/ norms.htm)

Posey section dubbed Stearnes and Mackey and a third piece on top of Home Plate called Larry Brown were the most dust free, providing the best Mini-TES spectra of the thinly bedded section (Figure 12a). Brushed rock targets investigated by the other instruments typically provide poor results with Mini-TES because the brushed spots do not fill the Mini-TES field of view.

[27] Although previous deconvolution of the average of these spectra indicated a significant pigeonite component [Squyres et al., 2007], a correction for dust on the Mini-TES pointing mirror [Smith et al., 2006] was newly implemented, overturning this result. The new deconvolution (Figure 11b) shows that basaltic glass remains the dominant component at $\sim 40 \%$ abundance, with plagioclase and olivine at $\sim 10 \%$ each, but the pyroxene component drops to a range of $5-10 \%$. Sulfates are required at $\sim 5 \%$ abundance to achieve a good fit. Secondary silicates also are required at abundances of $20-25 \%$.

\subsection{Reconciling Mössbauer and Mini-TES Results}

[28] Discrepancies between the mineralogy of the Irvine and Barnhill classes derived by Mössbauer and Mini-TES are a product of the sensitivities of the two instruments. For example, Mössbauer indicates significant magnetite and $n p$ ox in these rocks, while the Mini-TES suggests volcanic glass and in the Barnhill class, secondary silicates. Mössbauer is limited to examining Fe-bearing minerals and is capable of penetrating up to $\sim 200 \mu \mathrm{m}$ into the rock [Klingelhöfer et al., 2003]. Mini-TES is a remote sensing tool that depends on a rock's thermal properties and consequently can only examine the outermost surface and is susceptible to atmospheric effects and dust contamination.

[29] Np ox comprises up to $29 \%$ of the Fe in the Barnhill class and only $4-6 \%$ of the Fe in the Irvine class (Table 2), but is not indicated by Mini-TES. Np ox may be spectrally equivalent to the volcanic glass $(\sim 40 \%$ in the Barnhill class versus $15 \%$ in Irvine) that is indicated by Mini-TES (Table 3), if the glass is rich in $\mathrm{Fe}^{3+}[$ McSween et al., 2008]. It is unclear if the oxidized component seen by Mössbauer is actually the amorphous alteration product np ox, volcanic glass, or both. Although magnetite was indi-
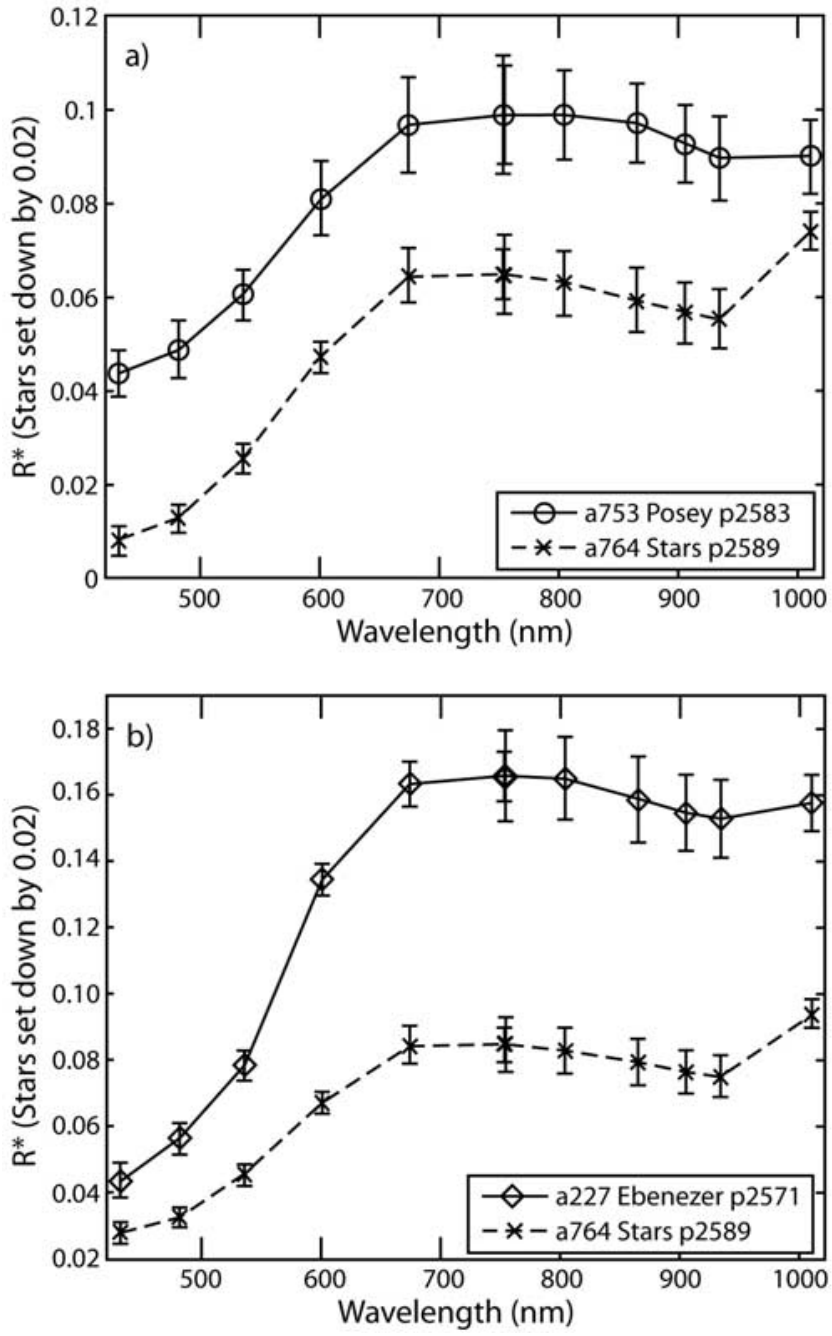

Figure 10. (a) VNIR multispectra graphs for the two endmembers CoolPapaBell_Stars and Posey_Manager brush spots. Suppression of reflectance in the $1009 \mathrm{~nm}$ band in the Posey spectrum is consistent with a higher fraction of opaque magnetite as is indicated by Mössbauer (Table 2). (b) VNIR multispectra graphs for CoolPapaBell_Stars and the Clovis class rock Ebeneezer brush spots. 

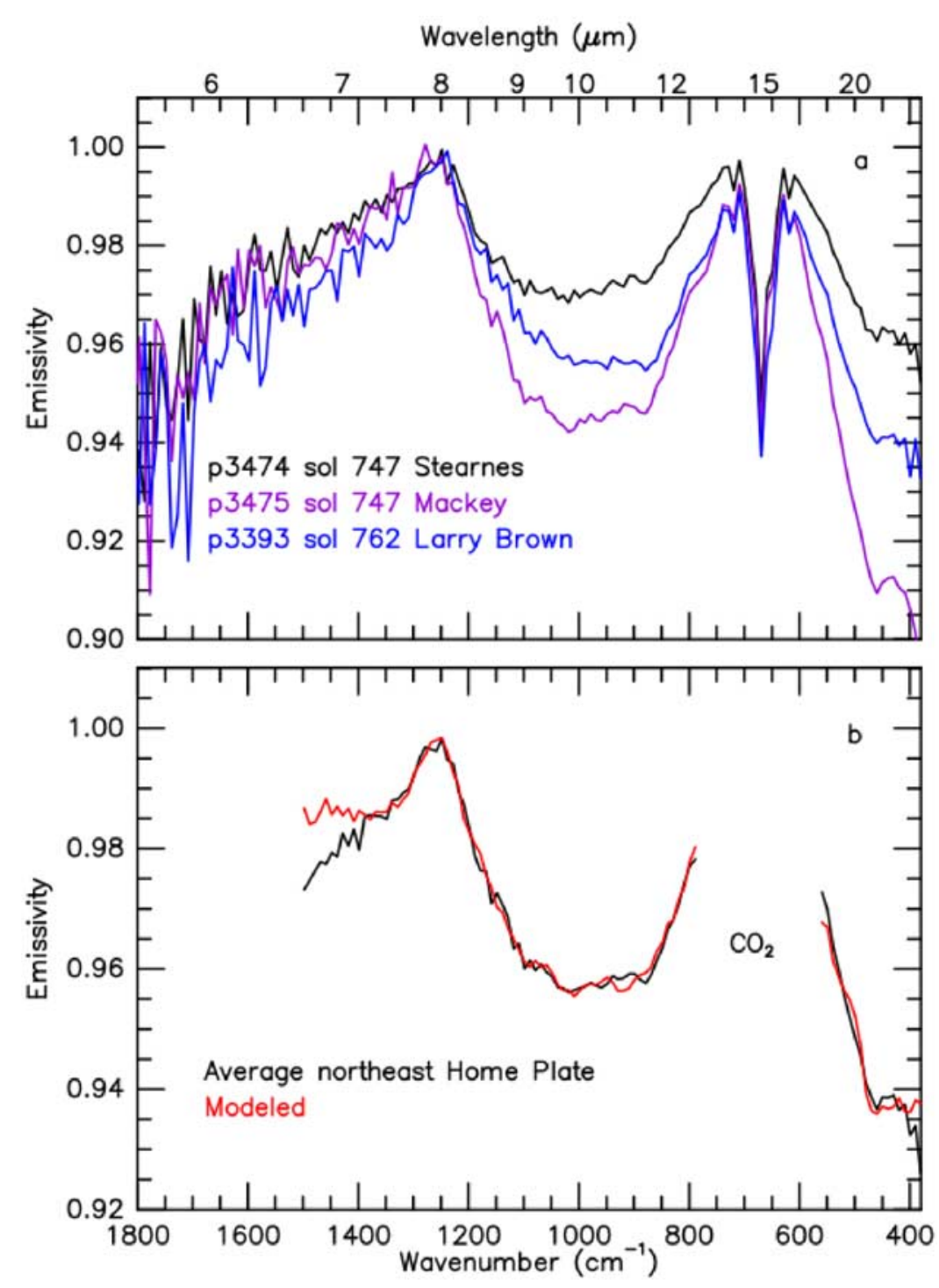

Figure 11. (a) Mini-TES spectra of the three best examples of layered rocks from the northeast outcrops of Home Plate (Barnhill class). (b) Spectral deconvolution of the average of the three spectra provides a good model fit with the component phases shown in Table 3.

cated by Mössbauer observations (Table 2) (Morris et al., submitted manuscript, 2008), its absence in the Mini-TES deconvolution results has been ascribed to the potential difficulty in identifying magnetite because portions of the spectra that are excluded from deconvolution coincide with important magnetite spectral features [Squyres et al., 2007].

\section{Primary Composition of Home Plate}

[30] The following discussion suggests that the Irvine class represents the unaltered, juvenile basaltic magma that fragmented and formed Home Plate. Compositionally, the Irvine and Barnhill classes are most like one another in nonvolatile major elements (Figure 5), including $\mathrm{Al}, \mathrm{Si}, \mathrm{Ca}$, $\mathrm{Ti}$, and $\mathrm{Fe}$ (Figure 6). Low-temperature chemical weathering at low water: rock ratios does not greatly affect the concentrations of these elements [Hurowitz et al., 2006a].
Nonvolatile major elements make up 88 to $93 \%$ of the Irvine and Barnhill rocks and consequently, their concentrations of these elements reflect a near primary composition. Both the Irvine and Barnhill classes contain primary igneous minerals, including high proportions of pyroxene and magnetite, as well as volcanic glass and have low proportions of plagioclase and olivine, according to the Mössbauer and Mini-TES. The igneous mineral assemblages identified by the instruments are corroborated by the CIPW norm calculations (Table 4), further linking the two rock classes.

[31] At terrestrial phreatomagmatic deposits, lava, scoria, air fall, and base surge deposits are commonly associated to one another, reflecting variable eruption dynamics (wet versus dry or explosive versus effusive) over the duration of an eruption or the lifespan of a volcano. Scoria producing Strombolian activity may either precede phreatomagmatism 
as at the Pinacate volcanic field, Mexico [Gutmann, 2002] or occur intermittently during or follow phreatomagmatism such as at Zuni Salt Lake, where scoria interlayers with air fall and base surge deposits and two later scoria cones formed within the maar crater [Ennis et al., 2007]. An increase in magma discharge rates over the course of an eruption may also favor dry Strombolian activity over phreatomagmatism as at Crater Hill, New Zealand [Houghton et al., 1996].

[32] Subtle geochemical differences among major elements, such as slightly higher $\mathrm{SiO}_{2}$ and lower $\mathrm{MgO}$ in the Irvine basalts suggest that, while related to one another, the Barnhill and Irvine class have experienced somewhat different igneous differentiation or chemical weathering histories. The three Irvine class basalts do not follow and lie well off apparent stratigraphic, nearly linear trends in the Barnhill class of increasing $\mathrm{SiO}_{2}, \mathrm{Al}_{2} \mathrm{O}_{3}, \mathrm{CaO}$, and $\mathrm{TiO}_{2}$ and decreasing $\mathrm{FeO}^{*}$ (Figures $6 \mathrm{a}$ and $6 \mathrm{~b}$ ). If two-component mixing was the process responsible for these linear trends in the Barnhill class, no Irvine class basalt target that has been analyzed so far can be a mixing end-member. We nevertheless use the Irvine class rock Masada as the best guess unaltered starting composition of the Barnhill class because they are most similar in major elements (Figure 4). Volatile elements were likely acquired after magma formation magma and fragmentation by some other process(es) because variations in most volatile elements are independent of variations in major elements (Figure 6).

[33] The Barnhill class is apparently more altered than the Irvine class, reflected in greater np ox contents (up to $29 \%$ of the $\mathrm{Fe}$ ) and yielding a greater $\mathrm{Fe}^{3+} / \mathrm{Fe}_{\text {Total }}$ (Table 2 ). High $\mathrm{Fe}^{3+} / \mathrm{Fe}_{\text {Total }}$ and high proportions of np ox have been interpreted to indicate intense aqueous alteration of the Clovis class rocks [Ming et al., 2006; Morris et al., 2006] that were found on Husband Hill. But if basaltic glass is needed to fit the Mini-TES spectra for the Irvine and Barnhill classes (Table 3), the np ox seen by Mössbauer could be pristine or devitrified glass [McSween et al., 2008]. Differences in the proportions of np ox or glass between the Barnhill and Irvine classes may reflect different degrees of devitrification or rates of cooling. Phreatomagmatic deposits quench rapidly during interaction with water and typically contain a greater proportion of volcanic glass than do basaltic scoria or lava.

[34] The eruption that produced Home Plate did not bring about the same alteration assemblages of Fe-bearing phases, such as smectite clay that are common in terrestrial base surges as indicated by visible and near-infrared (VNIR) reflectance [Farrand and Singer, 1992] and Mössbauer spectrometer. Secondary silicates were identified in the Barnhill class, but not in the Irvine class based on deconvolution of the Mini-TES spectra (Table 3). Ambient eruption conditions of the trigger fluid may have been too oxidizing for smectite to form. Also, the low-pressure atmospheric conditions on Mars may have caused water to rapidly evaporate instead of forming hydrated palagonitic minerals.

[35] Without the grinding capability of the RAT or microanalytical and isotopic analysis of returned samples, we are unable to undeniably confirm a relationship between the Irvine and Barnhill classes. Spatial, compositional, and mineralogical associations between the Home Plate and the nearby vesicular basalts, however, do support a petrogenetic link.

\section{Process of Halogen Enrichment at Home Plate}

[36] Barnhill class rocks acquired their excess volatile elements by some process(es) that must explain the following observations: (1) the Barnhill and Irvine classes appear to share a common magmatic source. (2) Variations in volatile elements are independent of variations in major and alkali elements, including in $\mathrm{SiO}_{2}, \mathrm{Al}_{2} \mathrm{O}_{3}, \mathrm{MgO}, \mathrm{CaO}$, $\mathrm{TiO}_{2}, \mathrm{Na}_{2} \mathrm{O}$, and $\mathrm{K}_{2} \mathrm{O}$. (3) $\mathrm{Cl}$ and $\mathrm{Br}$ contents are high relative to unaltered rocks examined in Gusev Crater, while $\mathrm{SO}_{3}$ concentrations are about the same. (4) the Barnhill class also has higher $\mathrm{Cl}$ than volatile-rich undisturbed Martian soils, which are elevated in both $\mathrm{SO}_{3}$ and $\mathrm{Cl}$ and have nearly constant $\mathrm{SO}_{3} / \mathrm{Cl}$ ratio (Figure 7a) [Haskin et al., 2005; Yen et al., 2005].

[37] Other $\mathrm{Cl}$ - and Br-rich rocks identified in Gusev Crater include a dark-toned, altered rind on the Adirondack class rock Mazatzal [Haskin et al., 2005], a few of the Algonquin class rocks (up to 1.4 wt \% $\mathrm{Cl}$ (Ming et al., manuscript in preparation, 2008)), and the Clovis class (up to $2.6 \mathrm{wt} \% \mathrm{Cl}$ [Gellert et al., 2006; Ming et al., 2006]). Although the Clovis class is similarly enriched in $\mathrm{Cl}$ and $\mathrm{Br}$, they have lower concentrations of $\mathrm{FeO}^{*}, \mathrm{Cr}_{2} \mathrm{O}_{3}, \mathrm{TiO}_{2}$, and $\mathrm{MnO}$, higher $\mathrm{MgO}$ and $\mathrm{Ni}$, and more variable in $\mathrm{SiO}_{2}$ and $\mathrm{Al}_{2} \mathrm{O}_{3}$ concentrations [Ming et al., 2006] than the Barnhill class. A similar source or process may have been responsible for the elevated $\mathrm{Cl}$ and $\mathrm{Br}$ in Clovis and Barnhill classes, but they were most likely derived from different primary basalt compositions.

[38] Halogen elements are highly soluble in aqueous fluids and are concentrated in almost any geologic brine, including evaporitic, cryogenic, hydrothermal, and primordial brines. The high degree of mobility of the halogens means that numerous processes can change their abundance. These include (1) igneous processes, such as fractional crystallization, partial melting, assimilation, and magma degassing, (2) salt coating and surface alteration, including as rock rinds, volcanic encrustation, and weathering, (3) fractional precipitation of evaporitic brine, and (4) hydrothermal brine addition or alteration.

\subsection{Igneous Processes}

[39] Because the grains that compose the Barnhill class are igneous, it is possible that primary igneous processes caused the high halogen concentrations. These include fractional crystallization, partial melting, crustal contamination, and fractional magma degassing.

[40] If fractional crystallization caused the enrichment in halogen elements at Home Plate, $\mathrm{Br}$ and $\mathrm{Cl}$ would be unfractionated as is observed in mid-ocean ridge basalts on Earth [Jambon et al., 1995]. In the Barnhill class, however, $\mathrm{Br} / \mathrm{Cl}$ varies by over a factor of 4 . Also, halogens would correlate with other similarly incompatible elements, such as the alkali element $\mathrm{K}$. Conversely, halogen and alkali-enriched, low-degree partial melts of the mantle would also have correlations between $\mathrm{Cl}$ and $\mathrm{K}$. This is not observed in the Barnhill class rocks. Partial melting of a different, volatile-enriched mantle source region could also account for high halogen concentrations, such as at terres- 
trial subduction zones [e.g., Kent et al., 2002]. But we see this as unlikely because the Cl-poor Irvine class basalts appear to share a common magmatic source.

[41] The assimilation of volatile element-enriched country rock may also contribute halogens to a magma. The Irvine and Barnhill class rocks are more primitive (have a higher $\mathrm{Mg} /(\mathrm{Mg}+\mathrm{Fe}))$ than Adirondack class basalts, which have been interpreted as near direct mantle melts in equilibrium with the Martian mantle at $1 \mathrm{GPa}$ [Monders et al., 2007]. This suggests that the Irvine and Barnhill classes are also near mantle melts and have not assimilated significant crustal melts.

[42] An oxidized magma that is under going open-system degassing will preferentially lose a S-rich vapor and evolve to lower $\mathrm{S} / \mathrm{Cl}$ and $\mathrm{S} / \mathrm{Br}$ ratios [Scaillet et al., 1998; Spilliaert et al., 2006]. If this were the cause of halogen enrichment in the Barnhill class, then Irvine class basalts would have similarly high $\mathrm{Cl}$ abundances and low $\mathrm{S} / \mathrm{Cl}$, but this is not the case (Table 1 and Figures 5 and 7).

\subsection{Coating and Surface Alteration}

[43] Unbrushed rock surfaces investigated by the twin rovers commonly contain greater concentrations of $\mathrm{Cl}, \mathrm{SO}_{3}$, $\mathrm{Ni}$, and $\mathrm{Zn}$ than brushed or RATted rock targets [Gellert et al., 2006]. The cause of this has been interpreted to be acid fog alteration [Banin et al., 1997] or low-temperature, low$\mathrm{a}_{\mathrm{H} 2 \mathrm{O}}$ chemical weathering [Haskin et al., 2005; Hurowitz et al., 2006a]. Concentrations of the highly soluble element $\mathrm{Br}$ at rock surfaces are variable in all geochemical classes investigated by the twin rovers [Gellert et al., 2006; Ming et al., 2006] and may imply that leaching of $\mathrm{Br}$ by ephemeral fluids occurs at the surface of rocks [Haskin et al., 2005]. Ratios of $\mathrm{Br} / \mathrm{Cl}$ vary by a factor of 4 in the Barnhill class and may reflect some mobile element leaching. This process is difficult to rule out entirely without the grinding capability of the RAT. If surface alteration and wicking of mobile elements processes were common on Mars, then the overall enrichment in $\mathrm{Cl}$ and $\mathrm{Br}$ in the Barnhill relative to Gusev soil, dust, and most other rock exteriors must be explained by some other process.

[44] Rinds have been identified on a few rocks in Gusev Crater, including the light-toned Adirondack class rock Mazatzal. Progressive abrasion of Mazatzal by the RAT removed a thin $(1-2 \mathrm{~mm})$, dark rind with higher $\mathrm{Cl}, \mathrm{Br}, \mathrm{Zn}$, and $\mathrm{K}_{2} \mathrm{O}$ than its basaltic interior [Haskin et al., 2005] (Figure 6). Mazatzal ranges to higher $\mathrm{Na} / \mathrm{Cl}$ and $\mathrm{Br} / \mathrm{Cl}$ than the Barnhill class, has systematically lower $\mathrm{Cl} / \mathrm{SO}_{3}$, and is more like undisturbed soils analyses (Figure 6). The $\mathrm{K}_{2} \mathrm{O}$ and $\mathrm{Cl}$ concentrations of the Mazatzal rind correlate very well $\left(\mathrm{R}^{2}=0.99\right.$; Figure $\left.7 \mathrm{~d}\right)$, suggesting the simple addition of $\mathrm{K}-\mathrm{Zn}-\mathrm{Cl}$ salt. Simple salt addition also appears to have also occurred in some Algonquin class, where a few targets have higher $\mathrm{K}_{2} \mathrm{O}$ concentrations (up to $0.9 \mathrm{wt} \%$ ), but have similar nonmobile major elements to other Algonquin rocks (Figure 7d) (Ming et al., manuscript in preparation, 2008). For the high- $\mathrm{K}_{2} \mathrm{O}$ Algonquin rocks, $\mathrm{K}_{2} \mathrm{O}$ correlates well with $\mathrm{Cl}\left(\mathrm{R}^{2}=0.91\right)$, as do $\mathrm{Zn}$ and $\mathrm{Br}$, suggesting that addition of a simple $\mathrm{K}-\mathrm{Zn}-\mathrm{Cl}-\mathrm{Br}$ salt can account for these variations. Without a functioning RAT, it is impossible to rule out a weathering rind on the Barnhill class rocks completely. But if there is a rind, it is not visible in MI images (Figures $3 \mathrm{~d}$ and $3 \mathrm{e}$ ) and is not like the simple salt rind on Mazatzal. No simple correlation exists between $\mathrm{Cl}$, $\mathrm{Br}, \mathrm{K}$, and $\mathrm{Zn}$ for the Barnhill class (Figure 7).

[45] One interesting model for the formation of salts and rinds on rock surfaces is by interaction with "acid fog" volcanic aerosols [Banin et al., 1997]. Near constant $\mathrm{SO}_{3} / \mathrm{Cl}$ in undisturbed soils and dust on Mars has been interpreted as the result of a well-mixed volcanic aerosol component in the "global dust" [Banin et al., 1997; Newsom et al., 1999]. This global dust has higher $\mathrm{SO}_{3} / \mathrm{Cl}, \mathrm{K}_{2} \mathrm{O} / \mathrm{Cl}$ and $\mathrm{Na} / \mathrm{Cl}$ ratios than Barnhill class rocks (Figure 6e) and appears to have affected Mazatzal [Haskin et al., 2005]. Although volcanic aerosols have likely contributed volatiles to other rocks in Gusev Crater, Home Plate has higher $\mathrm{Cl}$ concentrations than the global dust and was probably generated by some other process.

[46] The degassing of volatile elements from a magma or lava flow will encrust its surface vent with native sulfur, sulfates, halides, and amorphous silica. Under high-temperature and reducing conditions, halide salts will dominate the encrustation assemblage. As the magma cools, sulfates and native sulfur will precipitate [e.g., Oskarsson, 1981]. Because the $\mathrm{SO}_{3}$ contents in Barnhill class rocks are comparable to nearby basalts and no rind was observed, we consider this an unlikely explanation for the high halogen concentrations.

\subsection{Fractional Evaporation}

[47] The evolution of an evaporating brine depends on the initial composition of the fluid. In a S- and Cl-dominated system controlled by basalt weathering, sulfate precipitation precedes the formation of acidic Cl-rich brine, evolving toward lower $\mathrm{SO}_{3} / \mathrm{Cl}$ and higher $\mathrm{Br} / \mathrm{Cl}$ [Tosca et al., 2005; Tosca and McLennan, 2006]. In Martian nakhlite meteorites, for example, evaporation of fluids in fractures in cumulate olivine and in interstitial areas following the sequence of Ca-siderite, clay minerals, gypsum, anhydrite, and finally chloride salts [Bridges and Grady, 2000; Bridges et al., 2001]. Fractional evaporation under these conditions requires abundant sulfate precipitation along with or prior to chloride salt formation [Catling, 1999; Tosca and McLennan, 2006]. Although sulfate salts have been found in the vicinity of Home Plate as the friable Arad and Tyrone soils, they have limited distribution and contain geochemical signatures of nearby rocks, indicating a local source and fumarolic origin [Yen et al., 2008].

\subsection{Hydrothermal Brine Addition or Alteration}

[48] There are 3 possible models for the incorporation of a brine into the Barnhill class and each may have played a role: (1) brine assimilation while the basaltic magma rose through the crust, (2) brine addition during phreatomagmatic fragmentation, and (3) aqueous (hydrothermal) alteration. Our preferred model for Home Plate is brine addition during phreatomagmatic fragmentation that was later overprinted by hydrothermal alteration. This two-stage model is in agreement with rock textures and geochemical and spectral differences between the northwest and southeast sides of Home Plate (Figure 4). All three models, while difficult to differentiate without microanalytical or isotopic techniques require the presence of a persistent brine that was external to the volcanic system. 


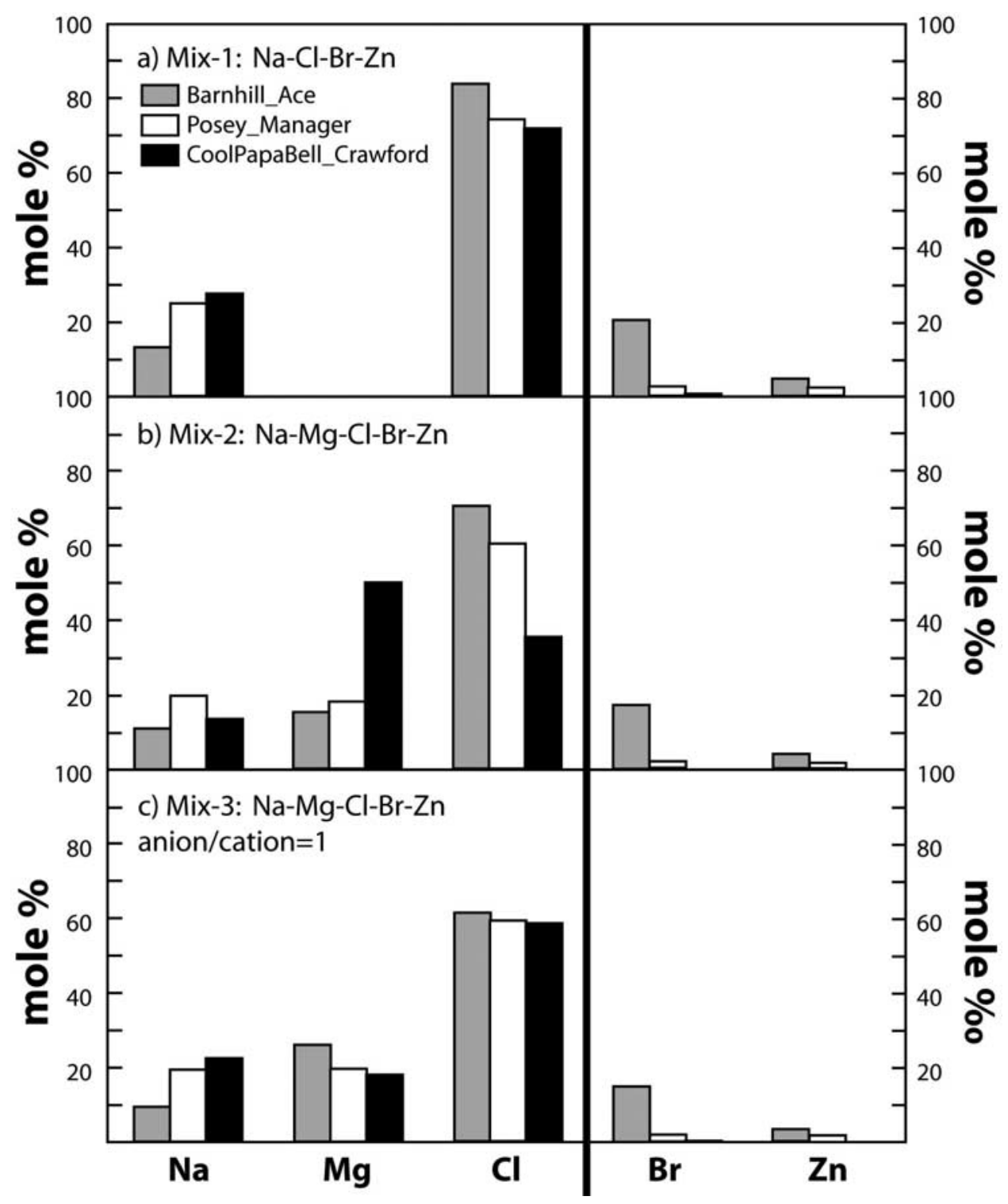

Figure 12. Bar graphs showing salt compositions deduced by two-component mix models (Table 5). Concentrations are shown in mol \% for $\mathrm{Na}, \mathrm{Mg}$, and $\mathrm{Cl}$ and in mol \%o for $\mathrm{Zn}$ and $\mathrm{Br}$. (a) Mix 1 used the ions $\mathrm{Na}, \mathrm{Cl}, \mathrm{Br}$, and $\mathrm{Zn}$. (b) Mix 2 used the ions $\mathrm{Na}, \mathrm{Mg}, \mathrm{Cl}, \mathrm{Br}$, and $\mathrm{Zn}$. (c) Mix 3 is the same as mix 2, but the anion/cation charge ratio was set.

Table 5. Mix Model Salt Compositions ${ }^{\mathrm{a}}$

\begin{tabular}{|c|c|c|c|c|c|c|c|}
\hline Rock & $\mathrm{Na}$ & $\mathrm{Mg}$ & $\mathrm{Cl}$ & $\mathrm{Br}$ & $\mathrm{Zn}$ & Anion/Cation & Mix Factor (\%) \\
\hline \multicolumn{8}{|c|}{ Model 1} \\
\hline Barnhill Ace & 13.3 & - & 84.1 & 2.08 & 0.51 & 6.0 & 0.9 \\
\hline Posey_Manager & 24.8 & - & 74.7 & 0.28 & 0.26 & 3.0 & 1.7 \\
\hline CoolPapaBell_Crawford & 27.7 & - & 72.2 & 0.11 & 0 & 2.6 & 1.0 \\
\hline \multicolumn{8}{|c|}{ Model 2} \\
\hline Barnhill_Ace & 11.2 & 15.7 & 71.0 & 1.75 & 0.43 & 1.7 & 1.1 \\
\hline Posey_Manager & 20.2 & 18.5 & 60.8 & 0.23 & 0.21 & 1.1 & 1.8 \\
\hline CoolPapaBell_Crawford & 13.8 & 50.4 & 35.8 & 0.05 & 0 & 0.3 & 1.0 \\
\hline \multicolumn{8}{|c|}{ Model 3} \\
\hline Barnhill_Ace & 9.8 & 26.5 & 61.9 & 1.53 & 0.37 & 1 & 1.1 \\
\hline Posey_Manager & 19.9 & 19.9 & 59.8 & 0.22 & 0.21 & 1 & 2.0 \\
\hline CoolPapaBell_Crawford & 22.7 & 18.2 & 59.0 & 0.09 & 0 & 1 & 1.0 \\
\hline
\end{tabular}

${ }^{\mathrm{a}}$ In mol \%. Mix models are (1) using only anions and cations that are significantly different in the Barnhill class from Masada, an Irvine class basalt; (2) including $\mathrm{Mg}$; and (3) setting anion/cation $=1$ and solving for mole $\% \mathrm{Mg}$ in salt. In the final model, the calculated Mg may also include other $2^{+}$ cations such as $\mathrm{Ca}$, or $\mathrm{Fe}^{2+}$. The anion/cation ratio $\left.=([\mathrm{Cl}]+[\mathrm{Br}]) /([\mathrm{Na}]+2[\mathrm{Mg}]+2 \mathrm{Zn}]\right)$. The mix factor is the percent salt added to the Masada. 


\subsubsection{Brine Assimilation}

[49] The assimilation of fluid by a magma is very common in terrestrial oceanic basalts as they interact with deeply circulating seawater in the crust [e.g., Michael and Schilling, 1989]. Brine assimilation is possible on Mars because subsurface fluids are more stable than under lowpressure atmospheric conditions, but there is no evidence for brine assimilation for any other basalts in Gusev Crater. 5.4.2. Brine Addition During Fragmentation

[50] The trigger fluid for the phreatomagmatic eruption that formed Home Plate may have been a briny groundwater that was incorporated during rapid quenching and subsequent hydration of the volcanic glass. On Earth for example, marine tuff rings, such as Surtsey, Iceland [Jakobsson and Moore, 1986], have quenched, hydrated glasses with high $\mathrm{Cl}$ concentrations that were acquired from seawater. The initial concentrations of dissolved constituents in the trigger fluid control their concentrations in the volcanic deposit. The character of the fluid can thus be understood by investigating fluid mobile elements in the phreatomagmatic deposit.

\subsubsection{Hydrothermal Alteration}

[51] Abundant evidence has been found by Spirit for a hydrothermal system at or near Home Plate, such as fumarolic deposits [Yen et al., 200] and highly altered rocks southeast of Home Plate, including some that have high silica [Squyres et al., 2008], high Zn (Ming et al., manuscript in preparation, 2008), or abundant hematite (Morris et al., submitted manuscript, 2008). Although the Barnhill rocks retain their initial igneous phenocryst assemblage, they contain more np ox than the Irvine class basalts. Some degree of hydrothermal alteration is therefore likely but appears to vary around the Home Plate structure as is suggested by differences in spectral slope from east to west across Home Plate (Figure 4) [Farrand et al., 2008]. Hydrothermal alteration of Home Plate would have been caused by an infiltrating, $\mathrm{Cl}-\mathrm{Br}-\mathrm{Zn}-\mathrm{Ge}$ hydrothermal brine that may have leached of $\mathrm{K}_{2} \mathrm{O}$. This brine did not appear to affect the nearby vesicular basalts. As alteration first occurs at void and grain boundaries [e.g., Driefand and Schiffman, 2004], contrasting permeability or reactivity between the massive basalt and the glass-rich clastic Barnhill may account for differences in degree of alteration.

[52] Enrichment of the volatile siderophile Ge at Home Plate further implicates a hydrothermal origin as Ge is often associated with $\mathrm{Zn}$ and $\mathrm{Cl}$ in hydrothermal ore deposits on Earth [Bernstein, 1985]. Ge has only been found at any notable abundance in a handful of rock classes by the twin rovers. These include the $\mathrm{Zn}$ - and $\mathrm{Cl}$-rich rind on Mazatzal [Haskin et al., 2005], the $\mathrm{SiO}_{2}$-rich FuzzySmith on top of Home Plate [Squyres et al., 2007], and Heat Shield Rock, an iron meteorite in Meridiani Planum [Schroder et al., 2008]. In the Barnhill class, Ge concentrations range between 16 and $71 \mathrm{ppm}$ (Table 1) (Ming et al., manuscript in preparation, 2008).

\section{Composition of the Brine}

[53] On Mars, subsurface fluids are expected to be loaded with dissolved solids because aquifer recharge rates are exceedingly low, residence times are very high, and waterrock interactions and magmatic heat and mass inputs are likely to be significant [e.g., Hoffman et al., 2000; Knauth and Burt, 2002]. If brine addition during fragmentation contributed volatile elements to Home Plate, the character of the brine can be fingerprinted by differences between the Barnhill class and their apparent unaltered equivalent, the Irvine basalts. A rough estimate of the composition of this groundwater fluid can be made by solving for the concentration of element $i$ in the salt component of the brine $\left(C_{\text {salt }}^{i}\right)$ in a simple two-component mix:

$$
C_{\text {salt }}^{i}\left(X_{\text {salt }}\right)+C_{\text {basalt }}^{i}\left(1-X_{\text {salt }}\right)=C_{\text {Barnhill }}^{i},
$$

where $X_{\text {salt }}$ is the fraction of salt added, $C_{\text {basalt }}^{i}$ is the concentration of element $i$ in Masada, the Irvine class basalt that is most like the Barnhill class (Figure 5), and $C_{\text {Barnhill }}^{i}$ is the concentration of element $i$ in the Barnhill targets Barnhill_Ace, Posey_Manager, and CoolPapaBell_Crawford (Table 1). Targets not included in this model are Barnhill Fastball, an outlier in major elements (Figure 6), and CoolPapaBell_Stars, which is very similar to Crawford. This simple mix model is limited because it ignores some important components and processes and consequently, should be treated as a minimum estimate for composition of the brine. As stated previously, no correlations exist among $\mathrm{Cl}, \mathrm{Br}, \mathrm{Zn}$, and $\mathrm{K}_{2} \mathrm{O}$, making the addition of a simple salt unlikely and may reflect overprinting by hydrothermal alteration. This simple two-component mix model also ignores surface dust and assumes perfect distribution of the aqueous phase $\left(D_{\text {magma }}^{\text {vapor }}=1\right)$.

[54] Three iterations of calculating a salt composition were performed and their results are presented in Table 5. In the first mix model (mix 1), only elements at concentrations in the Barnhill targets that are significantly different (greater than error; Table 1) from Masada were used. These include the anions $\mathrm{Cl}^{-}$and $\mathrm{Br}^{-}$and the cations $\mathrm{Na}^{+}$and $\mathrm{Zn}^{2+}$. The cation $\mathrm{K}^{+}$was not included because its concentrations are notably lower in the Barnhill class than in the Irvine class (Figure 5). The absence of $\mathrm{K}^{+}$in the mix model does not exclude the mix hypothesis because $\mathrm{K}_{2} \mathrm{O}$ may be related to the initial magma composition. Also, alkalis are easily leached by hydrothermal fluids or during palagonization [Fisher and Schmincke, 1984]. Because the resulting Cl-rich mix 1 salt (Figure 12 and Table 5) is not chargebalanced with an anion/cation ratio $\left(\left(\left[\mathrm{Cl}^{-}\right]+\left[\mathrm{Br}^{-}\right]\right) /\left(\left[\mathrm{Na}^{+}\right]+\right.\right.$ $\left.2\left[\mathrm{Zn}^{2+}\right]\right)$ in mol \%) of 2.6 to 6.0 , the mix 2 model included an additional cation, $\mathrm{Mg}^{2+}$. Concentrations of $\mathrm{MgO}$ are significantly greater in two of the three modeled Barnhill targets and the element $\mathrm{Mg}$ is considered a mobile element on Mars [King et al., 2004; Bridges and Grady, 2000; Tosca et al., 2004] as it is liberated by the dissolution of olivine [Burns, 1993]. Among the Barnhill rocks, $\mathrm{MgO}$ correlates with major element variations (e.g., $\mathrm{Al}_{2} \mathrm{O}_{3}, \mathrm{SiO}_{2}, \mathrm{CaO}$, and $\mathrm{TiO}_{2}$; Figures 5 and 7) that were probably caused by an independent igneous process, complicating the mix model. The anion/cation ratios in mix 2 salt are lower $(0.3-1.7)$ than the mix 1 salt but are not charge balanced. We address this as well as the unrelated major element variations that may control $\mathrm{MgO}$ in the final mix 3 calculation by fixing the anion/cation ratio as 1 (Table 5); concentrations of $\mathrm{Cl}$, $\mathrm{Br}, \mathrm{Na}$, and $\mathrm{Zn}$ were calculated with equation (1), but the $\mathrm{Mg}^{2+}$ concentration was calculated to fit the charge balance. The results in Table 5 are presented in $\mathrm{mol} \%$ and so the mix 
2 and mix $3 \mathrm{Mg}^{2+}$ concentrations really may be any divalent cation, such as $\mathrm{Fe}^{2+}$ or $\mathrm{Ca}^{2+}$.

[55] The three mix models found that the Barnhill class compositions can be made by combining a Masada-like basalt with $1-2 \% \mathrm{Mg}-\mathrm{Na}-\mathrm{Zn}-\mathrm{Cl}-\mathrm{Br}$ salt (Figure 12). The mass of the salt is only a fraction of the brine, however. If the brine was incorporated into the Barnhill rocks during a phreatomagmatic eruption, the concentration of dissolved solids in the brine can be estimated by extrapolating the amount fluid necessary to form soft sediment deformation textures, such as the bomb sag and vesicles at Home Plate. If $15-20 \%$ water is needed, based on terrestrial estimates [Heiken, 1972], the brine that interacted with the Barnhill class consists of $10-13 \%$ dissolved solids.

\subsection{Limits of the Simple Mix Model}

[56] Our knowledge of the composition of the Barnhill brine is limited by what can be analyzed by APXS as well as the volatility of the dissolved constituents. Dissolved ions, such as F-, $\mathrm{NH}_{4}$, hydrocarbons, or $\mathrm{CO}_{2}$, cannot be detected by APXS. In particular, dissolved carbon as $\mathrm{HCO}_{3}^{-}, \mathrm{CO}_{2}$, or $\mathrm{CO}$ can make up a significant proportion of total dissolved solids in terrestrial hydrothermal brines, particularly if they interact with carbonate country rock (e.g., Yellowstone Mammoth hot spring [Fournier, 1989]). Carbonates have been identified in Martian meteorites, including nakhlites [Bridges and Grady, 2000] and ALH84001 [e.g., Golden et al., 2000], indicating that $\mathrm{CO}_{3}$-saturated fluids have been stable near the Martian surface. Terrestrial phreatomagmatic eruptions release dissolved $\mathrm{CO}_{2}$ into the atmosphere because it strongly partitions into a vapor phase at low pressure, rather than precipitating a carbonate salt [Lowenstern, 2001]. If dissolved carbonate is present in the Barnhill brine, it could as much as double our salinity estimate.

[57] In spite of the simplified nature of the two-component mix (basalt + brine) model, we can constrain the composition of the dissolved salts in the brine to $\mathrm{Na}-\mathrm{Mg}-\mathrm{Zn}-\mathrm{Cl}-\mathrm{Br}$ $\left( \pm \mathrm{Fe}, \pm \mathrm{Ca}, \pm \mathrm{CO}_{2}\right.$ ). Overprinting hydrothermal alteration likely did occur, but was minor because igneous minerals have not been affected. The presence of abundant magnetite and nanophase $\mathrm{Fe}$ oxide instead of the $\mathrm{Fe}^{2+}$ smectite, a common phase in terrestrial palagonite, suggests that the brine is fairly oxidized. On Earth, Cl-dominated hydrothermal systems on Earth are typically neutral to slightly acidic (e.g., Yellowstone [Fournier, 1989]). Ferric iron is relatively soluble under low $\mathrm{pH}$ conditions. That we do not see evidence for $\mathrm{Fe}$ in the Barnhill brine suggests that it formed at a near neutral pH [e.g., Hurowitz et al., 2006b].

\subsection{Comparison With Other Planetary Brines}

[58] The Na-Mg-Zn-Cl-Br $\left( \pm \mathrm{Fe}, \pm \mathrm{Ca}, \pm \mathrm{CO}_{2}\right)$ brine estimated for the Barnhill class has the lowest ratio of $\mathrm{SO}_{3} / \mathrm{Cl}$ of Martian fluids that have been identified. The Barnhill brine is most similar to a $\mathrm{Mg}-\mathrm{Zn}-\mathrm{S}-\mathrm{Br}-\mathrm{Cl}$ brine modeled by a two-component mix with a relatively unaltered Watchtower class basalt that was followed by surface weathering to make the Wishstone class of Husband Hill [Hurowitz et al., 2006b]. Differences in the S content between the Wishstone and Barnhill brines may reflect either separate alteration or brine fractionation histories.
[59] Other fluids that have been identified on Mars have higher $\mathrm{SO}_{3} / \mathrm{Cl}$ than in the Barnhill brine and include primary, undifferentiated fluids, such as the S-rich volcanic aerosols in the global dust [Banin et al., 1997; Newsom et $a l ., 1999]$ and water-poor, primordial $\mathrm{Mg}-\mathrm{Na}-\mathrm{SO}_{4}-\mathrm{Cl}$ brines derived from the weathering of ultramafic rocks [King et al., 2004]. Also, the differentiated fluids that precipitated sulfates in Meridiani Planum have been estimated to have $\mathrm{SO}_{3} /$ $\mathrm{Cl}$ of about 30, resulting from the weathering of basalt by an influx of sulfuric acid [Tosca et al., 2004, 2005]. And finally, carbonate, sulfate, chloride, and clay minerals in the Martian nakhlite meteorites have been interpreted as the result of fractional precipitation of a Na-Mg-Fe-Ca-SO ${ }_{4}-\mathrm{Cl}-$ $\mathrm{H}_{2} \mathrm{O}-\mathrm{HCO}_{3}$ - acidic brine [Bridges and Grady, 2000; Catling, 1999; Sawyer et al., 2000] that leached mobile constituents from the mesostasis and olivine at low water:rock ratios [Rost et al., 2006; Bridges and Grady, 2000].

[60] The salinity of the Barnhill brine (10-13\% minimum estimate) is greater than that of terrestrial seawater $(\sim 3.5 \%)$ and dilute $\mathrm{Na}-\mathrm{Cl}$ hot springs (e.g., $0.16-0.46 \%$ [White, 1967]), where recharge by fresh, meteoric water is high. Terrestrial hydrothermal fluids have salinities that are more comparable to the brine at Home Plate. These fluids range from less than that of seawater to about that of magmatic fluids, or $\sim 55 \%$ [Nehlig, 1991]. The calculated salinity for the Barnhill brine is consistent with very low groundwater recharge rates and significant magmatic heat and mass inputs and high water:rock interactions.

\section{Hydrothermal Activity in Gusev Crater}

[61] Primary volcanic exhalents on Mars have an average $\mathrm{SO}_{3} / \mathrm{Cl}$ ratio $(\sim 8)$ like the Martian global dust [Banin et al., 1997; Newsom et al., 1999; Haskin et al., 2005]. The proximity of the Cl-dominated fluid identified at Home Plate and the Paso Robles class sulfate soils (up to $35.1 \mathrm{wt}$ $\% \mathrm{SO}_{3}$; Figure 7a), such as Dead_Sea and Tyrone (Figure 1) suggests that $\mathrm{Cl}$ and $\mathrm{SO}_{3}$ have been fractionated from one another. Boiling of a hydrothermal fluid is a particularly effective way for an acidic S-rich vapor to partition from a more neutral Cl-rich brine [e.g., Fournier, 1989]. If this is the case, then groundwater must have persisted in the Columbia Hills over the evolution of a magma system.

[62] Volatiles exsolved from fluid saturated magmas partition into immiscible S-rich vapor and dense Cl-rich brine. In terrestrial geothermal systems, it is rare for pure, superheated volcanic gases to reach the surface. Instead, circulating groundwater obtains heat and volcanic gasses from a magma at depth. Excess heat causes the aquifer to boil, releasing an acid sulfate vapor that is loaded with volatile metals that form S complexes [Heinrich et al., 1999]. At the surface, this vapor escapes at fumarolic vents or acid sulfate springs. The brine that is left behind after vapor extraction is Cl-rich, typically has a neutral $\mathrm{pH}$, and follows a different, often longer flow path. Cl-rich fluids are often discharged at springs at lower elevations than acid sulfate springs (such as at the Oregon Cascade Range [Ingebritsen et al., 1994]) or where permeability and recharge rates are great that deep brines can mix with the shallow groundwater (such as at Yellowstone [Fournier, 1989]). In Gusev Crater, acid sulfate vapors may have reached the surface as fumaroles or condensed as caustic pools that produced sulfates like those 
that have been found at Tyrone, Dead_Sea, and Paso Robles. The residual hydrothermal groundwater after vapor extraction is represented by the $\mathrm{Na}-\mathrm{Mg}-\mathrm{Zn}-\mathrm{Cl}-\mathrm{Br}( \pm \mathrm{Fe}, \pm \mathrm{Ca}$, $\left.\pm \mathrm{CO}_{2}\right)$ brine that has been identified at Home Plate and that incited phreatomagmatism and subsequent hydrothermal alteration.

[63] The ultimate origin of this Cl-rich brine is unknown, but it is probably not related to the degassing of the magma system that formed Home Plate or that directly contributed heat and volcanic gasses. Perfect degassing and accumulation from a magma with $1-5 \% \mathrm{H}_{2} \mathrm{O}$ with a volume approximately 3 to 15 times larger than the Home Plate structure is necessary for this to occur. If the Barnhill brine has entirely igneous origins, it must be related to a large, long-lived magma system. The fluid more likely came from an outside source, such as the Gusev flood event that carved the Ma'adim Vallis canyon. If the rocks at Home Plate formed in a cold, dry environment similar to the one today, it is likely that the water resided for some time as ground ice or porous salty slush in the near surface before it was melted by magmatism.

\section{Conclusions}

[64] The excess halogen and volatile siderophile elements found in the clastic Barnhill class rocks that make up Home Plate suggest a persistent aqueous and volcanic history in the Inner Basin in the Columbia Hills. The Na-Mg-Zn-Cl-Br ( $\pm \mathrm{Fe}, \pm \mathrm{Ca}, \pm \mathrm{CO}_{2}$ ) brine that interacted with Barnhill rocks by inciting phreatomagmatism and (or) by subsequent hydrothermal alteration has evolved to lower ratios of $\mathrm{SO}_{3} / \mathrm{Cl}$, likely through the extraction of an acid sulfate vapor during boiling of a geothermal system at depth. The investigation of the vicinity of Home Plate has yielded further evidence for a hydrothermal system, including acid sulfate fumarolic [Yen et al., 2008], amorphous silica [Squyres et al., 2008], high Zn, and hematite-rich deposits (Morris et al., submitted manuscript, 2008). The fluid system that the Spirit rover has discovered is completely unlike the sedimentary sulfate deposits found by Opportunity in Meridiani Planum and its geochemical character, distribution and habitability will continue to be assessed as Spirit carries on its traverse.

[65] Acknowledgments. Funding for Athena science team members was provided by NASA Mars Exploration Rover mission contracts through the Jet Propulsion Laboratory. We thank Scott McLennan and Allan Trieman for their careful reviews. Many thanks to the scientists and engineers who have made and continue to make Mars Rover science so successful.

\section{References}

Arvidson, R. E., et al. (2006), Overview of the Spirit Mars Exploration Rover Mission to Gusev Crater: Landing site to Backstay Rock in the Columbia Hills, J. Geophys. Res., 111, E02S01, doi:10.1029/ 2005JE002499.

Banin, A., F. X. Han, I. Kan, and A. Cicelsky (1997), Acidic volatiles and the Mars soil, J. Geophys. Res., 102, 13,341-13,356, doi:10.1029/ 97JE01160

Bell, J. F., III, et al. (2003), Mars Exploration Rover Athena Panoramic camera (Pancam) investigation, J. Geophys. Res., 108(E12), 8063, doi:10.1029/2003JE002070

Bernstein, L. R. (1985), Germanium geochemistry and mineralogy, Geochim. Cosmochim. Acta, 49, 2409-2422, doi:10.1016/00167037(85)90241-8.
Bridges, J. C., and M. M. Grady (2000), Evaporite mineral assemblages in the nakhlite (Martian) meteorites, Earth Planet. Sci., 176, 267-279, doi:10.1016/S0012-821X(00)00019-4.

Bridges, J. C., D. C. Catling, J. M. Saxton, T. D. Swindle, I. C. Lyon, and M. M. Grady (2001), Alteration assemblages in Martian meteorites: Implications for near-surface processes, Space Sci. Rev., 96, 365-392, doi:10.1023/A:1011965826553.

Burns, R. G. (1993), Rates and mechanisms of chemical weathering of ferromagnesian silicate minerals on Mars, Geochim. Cosmochim. Acta, $57,4555-4574$

Cabrol, N. A., et al. (2003), Exploring Gusev Crater with Spirit: Review of sciences objectives and testable hypotheses, J. Geophys. Res., 108(E12), 8076, doi:10.1029/2002JE002026.

Catling, D. C. (1999), A chemical model for evaporates on early Mars: Possible sedimentary tracers of the early climate and implications for exploration, J. Geophys. Res., 104, 16,453-16,469, doi:10.1029 1998JE001020

Christensen, P. R., et al. (2003), Miniature Thermal Emission Spectrometer for the Mars Exploration Rovers, J. Geophys. Res., 108(E12), 8064, doi:10.1029/2003JE002117

Crumpler, L. S., T. McCoy, M. Schmidt, and N. Cabrol (2007), Physical volcanology at Gusev Crater, Spirit rover, paper presented at Seventh International Conference on Mars, Lunar and Planetary Institute, Pasadena, Calif., 19-13 July.

Driefand, A., and P. Schiffman (2004), Very low-temperature alteration of sideromelane in hyaloclastites and hyalotuffs from Kilauea and Mauna Kea volcanoes: Implications for mechanism of palagonite formation, Clays Clay Miner., 52, 622-634, doi:10.1346/CCMN.2004.0520508.

Ennis, M. E., M. E. Schmidt, T. McCoy, W. Farrand, and N. Cabrol (2007) Hydrovolcano on Mars? A comparison of Home Plate, Gusev Crater and Zuni Salt Lake Maar, New Mexico, Lunar Planet. Sci. Conf., XXXVIII, Abstract 1966.

Farrand, W. H., and R. B. Singer (1992), Alteration of hydrovolcanic basaltic ash: Observations with visible and near-infrared spectrometry, J. Geophys. Res., 97, 17,393-17,408, doi:10.1029/92JB01075.

Farrand, W. H., J. R. Johnson, M. Schmidt, and J. F. Bell III (2008), VNIR spectral differences on natural and brushed/wind-abraded surfaces on Home Plate, Gusev Crater, Mars: Spirit Pancam and HiRISE color observations, Lunar Planet. Sci. Conf., XXXIV, Abstract 1774.

Fisher, R. V., and H.-U. Schmincke (1984), Pyroclastic Rocks, Springer, New York.

Fournier, R. O. (1989), Geochemistry and dynamics of the Yellowstone National Park hydrothermal system, Annu. Rev. Earth Planet. Sci., 17, 13-53, doi:10.1146/annurev.ea.17.050189.000305.

Gellert, R., et al. (2004), Chemistry of rocks and soils in Gusev Crater from the Alpha Particle X-ray Spectometer, Science, 305, 829-832, doi:10.1126/science.1099913

Gellert, R., et al. (2006), Alpha Particle X-Ray Spectrometer (APXS): Results from Gusev Crater and calibration report, J. Geophys. Res., 111, E02S05, doi:10.1029/2005JE002555.

Golden, D. C., D. W. Ming, C. S. Schwandt, R. V. Morris, V. Yang, and G. E. Lofgren (2000), An experimental study on kinetically-driven precipitation of calcium-magnesium-iron carbonates from solution: Implications for low-temperature formation of carbonates in Martian meteorite Allan Hills 84001, Meteorit. Planet. Sci. 35, 457-465.

Golombek, M. P., et al. (2003), Selection of the Mars Exploration Rover landing sites, J. Geophys. Res., 108(E12), 8072, doi:10.1029/ 2003JE002074

Gorevan, S. P., et al. (2003), Rock Abrasion Tool: Mars Exploration Rover mission, J. Geophys. Res., 108(E12), 8068, doi:10.1029/2003JE002061. Gutmann, J. T. (2002), Strombolian and effusive activity as precursors to phreatomagmatism: Eruptive sequence at maars of the Pinacate volcanic field, Sonora, Mexico, J. Volcanol. Geotherm. Res., 113, 345-356, doi:10.1016/S0377-0273(01)00265-7

Haskin, L. A., et al. (2005), Water alteration of rocks and soils on Mars at the Spirit rover site in Gusev Crater, Nature, 436, 66-69, doi:10.1038/ nature 03640 .

Heiken, G. (1972), Morphology and petrology of volcanic ashes, Geol. Soc. Am. Bull., 83, 1961-1988, doi:10.1130/0016-7606[1972]83[1961: MAPOVA]2.0.CO;2.

Heinrich, C. A., D. Guenther, A. Audetat, T. Ulrich, and R. Frischknecht (1999), Metal fractionation between magmatic brine and vapor, determined by microanalysis of fluid inclusions, Geology, 27, 755-758, doi:10.1130/0091-7613[1999]027<0755:MFBMBA>2.3.CO;2.

Herkenhoff, K. E., et al. (2003), Athena Microscopic Imager investigation, J. Geophys. Res., 108(E12), 8065, doi:10.1029/2003JE002076.

Hildreth, W. (1981), Gradients in silicic magma chambers: Implications for lithospheric magmatism, J. Geophys. Res., 86, 10,153-10,192, doi:10.1029/JB086iB11p10153. 
Hoffman, N., L. P. Knauth, S. Klonowski, D. Burt, R. S. Saunders, R. W. Zurek, P. T. Doran, and S. L. Forma (2000), Ideas about surface runoff features on Mars, Science, 290, 711-714, doi:10.1126/science.290. $5492.711 \mathrm{c}$

Houghton, B. F., C. J. N. Wilson, M. D. Rosenburg, I. E. M. Smith, and R. J. Parker (1996), Mixed deposits of complex magmatic and phreatomagmatic volcanism: An example from Crater Hill, Auckland, New Zealand, Bull. Volcanol., 58, 59-66.

Hurowitz, J. A., S. M. McLennan, N. J. Tosca, R. E. Arvidson, J. R. Michalski, D. W. Ming, C. Schröder, and S. W. Squyres (2006a), In situ and experimental evidence for acidic weathering of rocks and soils on Mars, J. Geophys. Res., 111, E02S19, doi:10.1029/2005JE002515.

Hurowitz, J. A., S. M. McLennan, H. Y. McSween Jr., P. A. DeSouza Jr., and G. Klingelhöfer (2006b), Mixing relationships and the effects of secondary alteration in the Wishstone and Watchtower Classes of Husband Hill, Gusev Crater, Mars, J. Geophys. Res., 111, E12S14, doi:10.1029/2006JE002795

Ingebritsen, S. E., R. H. Mariner, and D. R. Sherrod (1994), Hydrothermal systems of the Cascade Range, north-central Oregon, U. S. Geol. Soc. Prof. Pap., 1044-L, 86 pp.

Jakobsson, S. P., and J. G. Moore (1986), Hydrothermal minerals and alteration rates at Surtsey volcano, Iceland, Geol. Soc. Am. Bull., 97, $648-659$.

Jambon, A., B. Deruelle, G. Dreibus, and F. Pineau (1995), Chlorine and bromine abundance in MORB: The contrasting behavior of the MidAtlantic and East Pacific Rise and implications for chlorine geodynamic cycle, Chem. Geol., 126, 101-117, doi:10.1016/0009-2541(95)00112-4.

Johannsen, A. (1931), A Descriptive Petrography of the Igneous Rocks, vol. 1, in Introduction, Textures, Classification, and Glossary, 267 pp., Univ. of Chicago Press, Chicago, Ill.

Johnson, J. R., J. F. Bell, E. Cloutis, M. Staid, W. H. Farrand, T. McCoy, M. Rice, A. Wang, and A. Yen (2007), Mineralogic constraints on sulfur-rich soils from Pancam spectra at Gusev Crater, Mars, Geophys. Res. Lett., 34, L13202, doi:10.1029/2007GL029894.

Kent, A. J. R., D. W. Peate, S. Newman, E. M. Stolper, and J. A. Pearce (2002), Chlorine in submarine glasses from the Lau Basin: Seawater contamination and constraints on the composition of slab-derived fluids, Earth Planet. Sci. Lett., 202, 361-377, doi:10.1016/S0012821X(02)00786-0.

King, P. L., D. T. Lescinsky, and H. W. Nesbitt (2004), The composition and evolution of primordial solutions on Mars, with application to other planetary bodies, Geochim. Cosmochim. Acta, 68, 4993-5008, doi:10.1016/j.gca.2004.05.036.

Klingelhöfer, G., et al. (2003), Athena MIMOS II Mössbauer spectrometer investigation, J. Geophys. Res., 108(E12), 8067, doi:10.1029/ 2003JE002138.

Knauth, L. P., and D. M. Burt (2002), Eutectic brines on Mars: Origin and possible relation to young seepage features, Icarus, 158, 267-271, doi:10.1006/icar.2002.6866.

Lowenstern, J. B. (2001), Carbon dioxide in magma and implications for hydrothermal systems, Miner. Deposita, 36, 490-502, doi:10.1007/ s001260100185.

McSween, H. Y., et al. (2004), Basaltic rocks analyzed by the Spirit Rover in Gusev Crater, Science, 305, 842-845, doi:10.1126/science.3050842.

McSween, H. Y., et al. (2006a), Characterization and petrologic interpretation of olivine-rich basalts at Gusev Crater, Mars, J. Geophys. Res., 111, E02S10, doi:10.1029/2005JE002477.

McSween, H. Y., et al. (2006b), Alkaline volcanic rocks from the Columbia Hills, Gusev Crater, Mars, J. Geophys. Res., 111, E09S91, doi:10.1029/ 2006JE002698.

McSween, H. Y., et al. (2008), Mineralogy of volcanic rocks in Gusev Crater, Mars: Reconciling Mössbauer, Alpha Particle X-Ray Spectrometer, and Miniature Thermal Emission Spectrometer spectra, J. Geophys. Res., 113, E06S04, doi:10.1029/2007JE002970.

Michael, P. J., and J.-G. Schilling (1989), Chlorine in mid-ocean ridge magmas: Evidence for assimilation of seawater-influenced components, Geochim. Cosmochim. Acta, 53, 3131-3143, doi:10.1016/ 0016-7037(89)90094-X

Ming, D. W., et al. (2006), Geochemical and mineralogical indicators for aqueous processes in the Columbia Hills of Gusev Crater, Mars, J. Geophys. Res., 111, E02S12, doi:10.1029/2005JE002560.

Mittlefehldt, D. W., R. Gellert, T. McCoy, H. Y. McSween, and R. Li (2006), Possible Ni-rich mafic-ultramafic magmatic sequence in the Columbia Hills: Evidence from the Spirit Rover, Lunar Planet. Sci. XXXVII, Abstract 1505 .

Monders, A. G., E. Medard, and T. L. Grove (2007), Phase equilibria investigations of the Adirondack class basalts from the Gusev plains, Gusev Crater, Mars, Meteorit. Planet. Sci., 42, 131-148.

Morris, R. V., et al. (2006), Mössbauer mineralogy of rock, soil, and dust at Gusev Crater, Mars: Spirit's journey through weakly altered olivine basalt on the plains and pervasively altered basalt in the Columbia Hills, J. Geophys. Res., 111, E02S13, doi:10.1029/2005JE002584

Nehlig, P. (1991), Salinity of oceanic hydrothermal fluids: A fluid inclusion study, Earth Planet. Sci. Lett., 102, 310-325, doi:10.1016/0012821X(91)90026-E.

Newsom, H. E., J. J. Hagerty, and F. Goff (1999), Mixed hydrothermal fluids and the origin of the Martian soil, J. Geophys. Res., 104, 87178728 .

Oskarsson, N. (1981), The chemistry of Icelandic lava incrustations and the latest stages of degassing, J. Volcanol. Geotherm. Res., 10, 93-111, doi:10.1016/0377-0273(81)90057-3.

Rieder, R., R. Gellert, J. Brückner, G. Klingelhöfer, G. Dreibus, A. Yen, and S. W. Squyres (2003), The new Athena Alpha Particle X-Ray Spectrometer for the Mars Exploration Rovers, J. Geophys. Res., 108(E12), 8066, doi:10.1029/2003JE002150.

Rost, D., E. P. Vicenzi, and M. Fries (2006), A Host for lithium in MIL03346 and implications for aqueous alteration on Mars, Lunar Planet. Sci. Conf., XXXVII, Abstract 2362

Ruff, S. W., P. R. Christensen, D. L. Blaney, W. H. Farrand, J. R. Johnson, J. R. Michalski, J. E. Moersch, S. P. Wright, and S. W. Squyres (2006), The rocks of Gusev Crater as viewed by the Mini-TES instrument, J. Geophys. Res., 111, E12S18, doi:10.1029/2006JE002747.

Sawyer, D. J., M. D. McGehee, J. Canepa, and C. B. Moore (2000), Water soluble ions in Nakhla Martian meteorite, Meteorit. Planet. Sci., 35, $743-747$.

Scaillet, B., B. Clemente, B. W. Evans, and M. Pichavent (1998), Redox control of sulfur degassing in silicic magmas, J. Geophys. Res., 103 , 23,937-23,949, doi:10.1029/98JB02301

Schroder, C. (2008), Meteorites on Mars observed with the Mars exploration rovers, J. Geophys. Res., 113, E06S22, doi:10.1029/2007JE002990.

Smith, M. D., M. J. Wolff, N. Spanovich, A. Ghosh, D. Banfield, P. R. Christensen, G. A. Landis, and S. W. Squyres (2006), One Martian year of atmospheric observations using MER Mini-TES, J. Geophys. Res., 111, E12S13, doi:10.1029/2006JE002770.

Spilliaert, N., N. Métrich, and P. Allard (2006), S-Cl-F degassing patter of water-rich alkali basalt: Modelling and relationship with eruption styles on Mount Etna volcano, Earth Planet. Sci. Lett., 248, $772-786$, doi:10.1016/j.epsl.2006.06.031.

Squyres, S. W., et al. (2003), Athena Mars Rover Science Investigation, J. Geophys. Res., 108(E12), 8062, doi:10.1029/2003JE002121.

Squyres, S. W., et al. (2004a), The Spirit Rover's Athena Science Investigation at Gusev Crater, Mars, Science, 305, 794-799, doi:10.1126/ science. 3050794 .

Squyres, S. W., et al. (2004b), In Situ evidence for an ancient aqueous environment at Meridiani Planum, Mars, Science, 306, 1709-1714, doi:10.1126/science. 1104559 .

Squyres, S. W., et al. (2006), Rocks of the Columbia Hills, J. Geophys. Res., 111, E02S11, doi:10.1029/2005JE002562.

Squyres, S. W., et al. (2007), Pyroclastic activity at Home Plate in Gusev Crater, Mars, Science, 316, 738-742, doi:10.1126/science.1139045.

Squyres, S. W., et al. (2008), Detection of silica-rich deposits on Mars, Science, 320, 1063-1067, doi:10.1126/science.1155429.

Tosca, N. J., and S. M. McLennan (2006), Chemical divides and evaporate assemblages on Mars, Earth Planet. Sci. Lett., 241, 21-31, doi:10.1016/ j.epsl.2005.10.021.

Tosca, N. J., S. M. McLennan, D. H. Lindsley, and M. A. A. Schoonen (2004), Acid-sulfate weathering of synthetic Martian basalt: The acid fog model revisited, J. Geophys. Res., 109, E05003, doi:10.1029/ 2003JE002218.

Tosca, N. J., S. M. McLennan, B. C. Clark, J. P. Grotzinger, J. A. Hurowitz, A. H. Knolll, C. Schroder, and S. W. Squyres (2005), Geochemical modeling of evaporation processes on Mars: Insight from the sedimentary record at Meridiani Planum, Earth Planet. Sci. Lett., 240, 122-148, doi:10.1016/j.epsl.2005.09.042.

White, D. E. (1967), Mercury and base-metal deposits with associated thermal and mineral waters, in Geochemistry of Hydrothermal Ore Deposits, edited by H. L. Barnes, pp. 575-631, Holt, Rinehart and Winston, New York.

Yen, A. S., et al. (2005), An integrated view of the chemistry and mineralogy of Martian soils, Nature, 436, 49-54, doi:10.1038/nature03637.

Yen, A. S., et al. (2008), Hydrothermal processes at Gusev Crater: An evaluation of Paso Robles class soils, J. Geophys. Res., 113, E06S10, doi:10.1029/2007JE002978

N. Cabrol, NASA Ames Research Center, MS 245-3, Moffett Field, CA 94035-1000, USA.

W. H. Farrand, Space Science Institute, 4750 Walnut Street, Suite 205, Boulder, CO 80301, USA. 
R. Gellert, Department of Physics, University of Guelph, MacNaughton Building, Gordon Street, Guelph, ON N1G 2W1, Canada.

J. R. Johnson, Astrogeology Team, U.S. Geological Survey, 2255 N. Gemini Drive, Flagstaff, AZ 86001, USA.

K. W. Lewis, Division of Geological and Planetary Sciences, California Institute of Technology, MC 150-21, Pasadena, CA 91125, USA.
T. J. McCoy and M. E. Schmidt, Department of Mineral Sciences, National Museum of Natural History, Smithsonian Institution, 10th and Constitution Avenues, N.W., Washington, DC 20560-0119, USA. (schmidtm@si.edu)

D. W. Ming, R. V. Morris, and C. Schroeder, NASA Johnson Space Center, Code KR, 2101 NASA Parkway, Houston, TX 77058-2906, USA.

S. W. Ruff, School of Earth and Space Exploration, Arizona State University, Tempe, AZ 85287-6305, USA. 